\title{
Plasticity of Lh cells caused by cell proliferation and recruitment of existing cells
}

\author{
Romain Fontaine, Eirill Ager-Wick, Kjetil Hodne and Finn-Arne Weltzien \\ Department of Basic Sciences and Aquatic Medicine, Faculty of Veterinary Medicine, Norwegian University of Life Sciences, Oslo, Norway \\ Correspondence should be addressed to F-A Weltzien: finn-arne.weltzien@nmbu.no
}

\begin{abstract}
Luteinizing hormone (Lh) and follicle-stimulating hormone (Fsh) control reproduction in vertebrates. Using a transgenic line of medaka, in which green fluorescent protein expression is controlled by the endogenous $/ \mathrm{hb}$ promotor, we studied development and plasticity of Lh cells, comparing juveniles and adults of both genders. Confocal imaging and 3D reconstruction revealed hypertrophy and hyperplasia of Lh cells in both genders from juvenile to adult stages. We show that Lh cell hyperplasia may be caused by recruitment of existing pituitary cells that start to produce $I h b$, as evidenced by time lapse recordings of primary pituitary cell cultures, and/or through Lh cell proliferation, demonstrated through a combination of 5-bromo-2'-deoxyuridine incubation experiments and proliferating cell nuclear antigen staining. Proliferating Lh cells do not belong to the classical type of multipotent stem cells, as they do not stain with anti-sox2. Estradiol exposure in vivo increased pituitary cell proliferation, particularly Lh cells, whereas pituitary Ihb and gpa expression levels decreased. RNA-seq and in situ hybridization showed that Lh cells express two estrogen receptors, esr 1 and esr $2 b$, and the aromatase gene cyp19a1b, suggesting a direct effect of estradiol, and possibly androgens, on Lh cell proliferation. In conclusion, our study reveals a high degree of plasticity in the medaka Lh cell population, resulting from a combination of recruitment and cell proliferation.
\end{abstract}

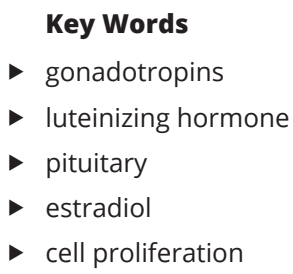

Journal of Endocrinology (2019) 240, 361-377

\section{Introduction}

The gonadotropins luteinizing hormone (Lh) and follicle-stimulating hormone (Fsh) are key players in the vertebrate brain-pituitary-gonad (BPG) axis controlling sexual maturation. Whereas the equivalent hormones in mammals and birds are synthesized and secreted from the same cell in the pituitary (Pope et al. 2006), they are produced by distinct cells in most teleosts (Kanda et al. 2011, Weltzien et al. 2014). Teleosts are therefore ideal models for investigating gonadotropin development and regulation.

Although described in only a few species, rainbow trout (Nozaki et al. 1990), African catfish (Cavaco et al.
2001) and zebrafish (Golan et al. 2014), the pituitary grows during the entire lifespan in teleosts, with a particular increase in the gonadotrope cell population during puberty. However, whether gonadotrope hyperplasia is a result of recruitment of existing pituitary cells and/or proliferation of progenitor cells is unknown. Controlling mechanisms are also poorly understood.

Gonadotropin synthesis and secretion are mainly stimulated by gonadotropin-releasing hormone, Gnrh. In addition, a variety of stimulatory and inhibitory factors from the brain participate in control of Lh and Fsh, with variable importance according to species and 
life stage (Yaron et al. 2003, Zohar et al. 2010). Gonadal steroids also participate in control, through direct and indirect feedback mechanisms, allowing the continuous communication within the BPG axis that is necessary for synchronized and coordinated activity.

Diverging effects of steroids on gonadotropes have been reported, depending on species, physiological status or gonadal steroid examined. Both positive and negative feedback effects have been observed on the synthesis and release of Lh and Fsh in teleosts (Yaron et al. 2003, Zohar et al. 2010, Von Krogh et al. 2017). The precise effects of sex steroids at the pituitary level are far from fully deciphered, and the mechanisms involved are likely to be complex as steroids can also act at the brain level.

Medaka (Oryzias latipes) provides a useful model system, having genetic gender determination (Matsuda et al. 2002, 2007, Nanda et al. 2002) and being accessible to a range of molecular and genetic tools (Wittbrodt et al. 2002, Shima \& Mitani 2004). In this study, we used the $\operatorname{tg}(\mathrm{lhb}$-hrGfpII) line (Hildahl et al. 2012) to study developmental changes in pituitary morphology and Lh cell population in both genders. We investigated whether LH cell plasticity may be due to both recruitment of existing pituitary cells and cell proliferation.

\section{Materials and methods}

\section{Animal maintenance and sexing}

Wild-type (WT, d-rR strain) and tg (lhb-hrGfpII) (Hildahl et al. 2012) medaka (Oryzias latipes) were maintained at $28^{\circ} \mathrm{C}$ on a $14 / 10 \mathrm{~h} \mathrm{light/darkness} \mathrm{cycle} \mathrm{in} \mathrm{a} \mathrm{re-circulating}$ water system and three daily feedings. Experiments were performed according to the recommendations on the care and welfare of research animals at the Norwegian University of Life Sciences. Experiments using 5-bromo2 '-deoxyuridine (BrdU) were approved by the Norwegian Food Safety Authority (FOTS ID 8596). Juvenile (2-monthold) and adult (6-month-old) fish were sexed based on secondary sexual characters (Egami 1975), confirmed by genotyping (Ager-Wick et al. 2014).

\section{Estradiol treatment}

To study effects of estradiol on cell proliferation, adult fish (six females and six males) were incubated for 2 or 6 days in system water containing $100 \mu \mathrm{g} / \mathrm{L}\left(3.7 \times 10^{-7} \mathrm{M}\right)$ estradiol (Sigma, diluted 1:105 in either dimethyl sulfoxide or $96 \%$ ethanol). Control fish (six of each gender) were incubated for 6 days with diluent only. A similar set-up was used to study the effects of estradiol on pituitary lhb and gpa synthesis, comparing adult fish (seven of each gender) incubated in system water containing estradiol with fish incubated with diluent only.

\section{Quantitative polymerase chain reaction (qPCR)}

After estradiol treatment, total RNA from single pituitaries was extracted in TRIzol (Ambion) and cDNA prepared from 30 ng total RNA. qPCR was performed as previously described (Weltzien et al. 2005) with minor modifications, using a LightCycler96 with SYBR Green I (Roche) and specific primers (Table 1) designed with Primer3Plus software (Untergasser et al. 2007). PCR cycling parameters were $300 \mathrm{~s}$ at $95^{\circ} \mathrm{C}$ followed by 40 cycles at $95^{\circ} \mathrm{C}$ for $10 \mathrm{~s}, 60^{\circ} \mathrm{C}$ for $10 \mathrm{~s}$ and $72^{\circ} \mathrm{C}$ for $6 \mathrm{~s}$, followed by melting curve analysis to assess qPCR product specificity. Samples were run in duplicate on cDNA diluted 1:5. Relative expression levels were calculated as described (Weltzien et al. 2005), using the most stable combination of three selected reference genes ( $r n a 18 s, r p l 7, g a p d h)$, according to RefFinder (Kim et al. 2010).

\section{In situ hybridization (ISH)}

ISH and fluorescent ISH (FISH) for lhb, esr1 (Er $\alpha), e s r 2 b$ $(\operatorname{Er} \beta 2)$ and cyp19a1b were performed as previously described (Fontaine et al. 2013). esr1 and esr2b were cloned using primers from Zempo et al. (2013), while for lhb and cyp19a1b, we used previously described riboprobes (Okubo et al. 2011, Hildahl et al. 2012). Control experiments were performed with sense riboprobes. For confirmation of $\operatorname{tg}(\mathrm{lhb}$-hrGfpII), in toto pituitaries were hybridized with $l h b$-fluorescein (FITC) riboprobe for $18 \mathrm{~h}$ at $65^{\circ} \mathrm{C}$. For esr 1 , esr $2 b$ and cyp19a1b ISH and $\mathrm{FISH}$, free-floating $60 \mu \mathrm{m}$ vibratome sections (Leica) were hybridized with digoxigenin-tagged (DIG) riboprobes for $18 \mathrm{~h}$ at $55^{\circ} \mathrm{C}$. Color revelation was performed with sheep anti-DIG, and anti-FITC conjugated with peroxidase (1:250; Roche), together with custom-made TAMRAconjugated and FITC-conjugated tyramides for FISH or with alkaline phosphatase (1:3000; Roche) and NBT/BCIP (Roche) for ISH.

\section{Lh cell proliferation}

(1) To count and locate newborn Lh cells, juvenile and adult $\operatorname{tg}(\operatorname{lh} b$-hrGfpII) fish were treated with $1 \mathrm{mM}$ BrdU (Sigma) diluted in water with $15 \%$ DMSO for $4 \mathrm{~h}$. They were then left for 4 days, without BrdU, under standard 
Table 1 List of the primers used for qPCR.

\begin{tabular}{lll}
\hline & & Accession number \\
Ihb & NM_001137653.2 \\
gpa & NM_001122906 \\
rna18s & AB105163.1 \\
rpl7 & NM_001104870 \\
gapdh & XM_004077972.3 \\
\hline
\end{tabular}

\begin{tabular}{l}
\hline Forward primer \\
\hline CCACTGCCTTACCAAGGACC \\
CCAATCTGGCTTCCTCAAAC \\
CCTGCGGCTTAATTTGACTC \\
TGCTTTGGTGGAGAAAGCTC \\
CCTCCATCTTTGATGCTGGT \\
\hline
\end{tabular}

\begin{tabular}{l} 
Reverse primer \\
\hline AGGAAGCTCAAATGTCTTGTAG \\
GCTCTGGAGAAGCAACATCC \\
AACTAAGAACGGCCATGCAC \\
TGGCAGGCTTGAAGTTCTTT \\
ACGGTTGCTGTAGCCAAACT \\
\hline
\end{tabular}

\begin{tabular}{l}
\hline PCR efficiency \\
\hline 2 \\
1.96 \\
2.02 \\
2.03 \\
2
\end{tabular}

conditions to allow dividing cells to complete mitosis and express differentiated markers such as Gfp. (2) To determine the location of dividing cells, three groups of adult $\operatorname{tg}(l h b$-hrGfpII) fish were treated with BrdU for $2,1 \mathrm{~h}$ or $30 \mathrm{~min}$, and then killed directly. (3) To investigate the effect of estradiol exposure on cell proliferation, fish were incubated with BrdU for $4 \mathrm{~h}$ immediately after estradiol treatment and then killed. Brain and pituitary were fixed in $4 \%$ paraformaldehyde overnight, and gradually dehydrated and stored in 100\% MetOH until use.

\section{Immunofluorescence}

Immunofluorescence (IF) was performed on free-floating $60 \mu \mathrm{m}$ sections as previously described (Fontaine et al. 2013). For BrdU IF and proliferating cell nuclear antigen (PCNA) IF, epitope retrieval was achieved using either $2 \mathrm{M}$ $\mathrm{HCl}$ (in PBS with $0.1 \%$ Tween) for $1 \mathrm{~h}$ at $37^{\circ} \mathrm{C}$ or HistoVT One (Nacalai Tesque, Japan) for $20 \mathrm{~min}$ at $90^{\circ} \mathrm{C}$. Then, a blocking step of $1 \mathrm{~h}$ was followed by primary antibody incubation: rat anti-BrdU (1:250; Abcam), mouse antiratPCNA (1:100; Santa Cruz Biotechnology) or custommade polyclonal rabbit anti-medakaLh $\beta$ (1:2000 (Burow et al. 2018)). For goat anti-human Sox2 (1:500; Immune Systems, UK), blocking was prepared according to supplier recommendations. Amplification was performed using AlexaFluor 555 or 647 secondary antibodies (1:1000; Invitrogen). Nuclei in Lh $\beta$-IF and Sox2-labeled tissues were stained with DAPI (1:1000; 4',6-diamidino2-phenylindole dihydrochloride; Sigma). Control experiments were performed using the same protocol without primary antibody.

\section{Dispersed pituitary cell culture}

Cell cultures ( $n=5$ of each gender) were prepared by dissociating cells from $15 \operatorname{tg}(l h b$-hrGfpII) adult pituitaries, as described in detail in Ager-Wick et al. (2018). Cells were plated in a glass-bottomed dish (Mattek, USA) in modified L-15 medium (Life Technologies), adjusted to $\mathrm{pH} 7.75$ and $290 \mathrm{mosmol} / \mathrm{kg}$ by incubating at $26^{\circ} \mathrm{C}$ with $1 \% \mathrm{CO}_{2}$.

\section{RNA-seq analysis}

Read counts for genes of interest were determined using data previously published in Ager-Wick et al. (2014), and summarized at the level of Ensembl annotated genes. Raw read counts were normalized using conditional quantile normalization with the R-package cqn (version 1.6.0) (Hansen et al. 2012).

\section{Imaging}

Vibratome slices were mounted between slide and coverslip with Vectashield (H-1000 Vector, UK) mounting medium, and spacers added between the slice and the coverslip when mounting whole pituitaries. Time lapse recordings of dissociated pituitary cells were performed in a humid chamber at $26^{\circ} \mathrm{C}$ with $1 \% \mathrm{CO}_{2}$, conditions optimized for medaka (Ager-Wick et al. 2018). Confocal images were acquired using a LSM710 microscope (Zeiss) with $10 \times$ (N.A. 0.3 ), $25 \times$ (N.A. 0.8 ) or $40 \times$ (N.A. $1.2)$ objectives. Channels were acquired sequentially to avoid signal crossover between filters. Images were taken with a zoom stereomicroscope (Nikon) and a sCMOS camera (Andor Zyla, UK). Images were processed using ZEN software (v2009, Zeiss). Z-projections from confocal image stacks were obtained using Fiji (v2.0.0 (Schindelin et al. 2012)). 3D reconstruction was built using 3D viewer plugin (Schmid et al. 2010).

\section{Cell counting and measurements}

Counting and measurements were performed blindly, including body weight, standard length and brain and pituitary sizes measured on fixed tissue $(n=10-12)$. Pituitaries were measured in three dimensions, and volume was estimated by height $\times$ width $\times$ length. Gfp cells were measured in $60 \mu \mathrm{m}$ parasagittal fixed brainpituitary slices $(n=5)$. For each fish, the 15 largest Gfppositive cells from three different slices were manually measured in two orthogonal axes using ZEN software. Cells were counted in whole fixed and DAPI-treated $(5 \mathrm{~h})$ pituitaries $(n=7-9)$. Selected $\mathrm{z}$-sections were 
analyzed using Cell Profiler software (v2.1.0 (Carpenter et al. 2006)) (Supplementary Fig. 1, see section on supplementary data given at the end of this article). BrdU-labeled and double-labeled cells (BrdU and Gfp) were manually counted using Fiji and cell-counter plugin. The fluorescence intensity in the mean region of interest (ROI) was measured with Fiji on a cell culture using $10 \times$ objective ( $n=11$ cells), and ROI of exactly the same area. Mean ROI fluorescence intensity was adjusted based on background levels from two ROI.

\section{Statistics}

Data were analyzed using GraphPad Prism (v6.0c) with significance set at $P<0.05$. Nonparametric analyses were used when data did not meet the Shapiro-Wilk normality test. Potential pituitary or brain size differences were tested by two-way ANOVA, followed by Tukey's multiple comparison test. Potential differences in body weight, standard length, pituitary cell number or proportion and effects of estradiol on cell proliferation were tested by one-way ANOVA and Tukey's. Correlations between pituitary length or volume and body weight or standard length were tested using Pearson correlation coefficients (R2), separating genders and stages. $\mathrm{R} 2$ of $0.75,0.50$, and 0.25 were described as substantial, moderate, or weak, respectively, according to (Henseler et al. 2009). KruskalWallis followed by Dunn's multiple comparisons test (nonparametric) was used to test for differences in the number of BrdU-Gfp-labeled cells. After removing outliers using the ROUT method, qPCR data were analyzed by oneway ANOVA followed by Tukey's multiple comparison test. Due to lack of normal distribution, lhb in females were tested by Kruskal-Wallis followed by Dunn's multiple comparisons test.

\section{Results}

\section{Verification of Ihb-transgenic line}

The high specificity of the $\operatorname{tg}(\mathrm{lhb}$-hrGfpII) line (Hildahl et al. 2012) in both adult and juvenile fish was confirmed by the clear overlap between Gfp-labeled cells and $l h b$ expressing cells labeled by FISH as well as Lh $\beta$-producing cells labeled by IF (Fig. 1).
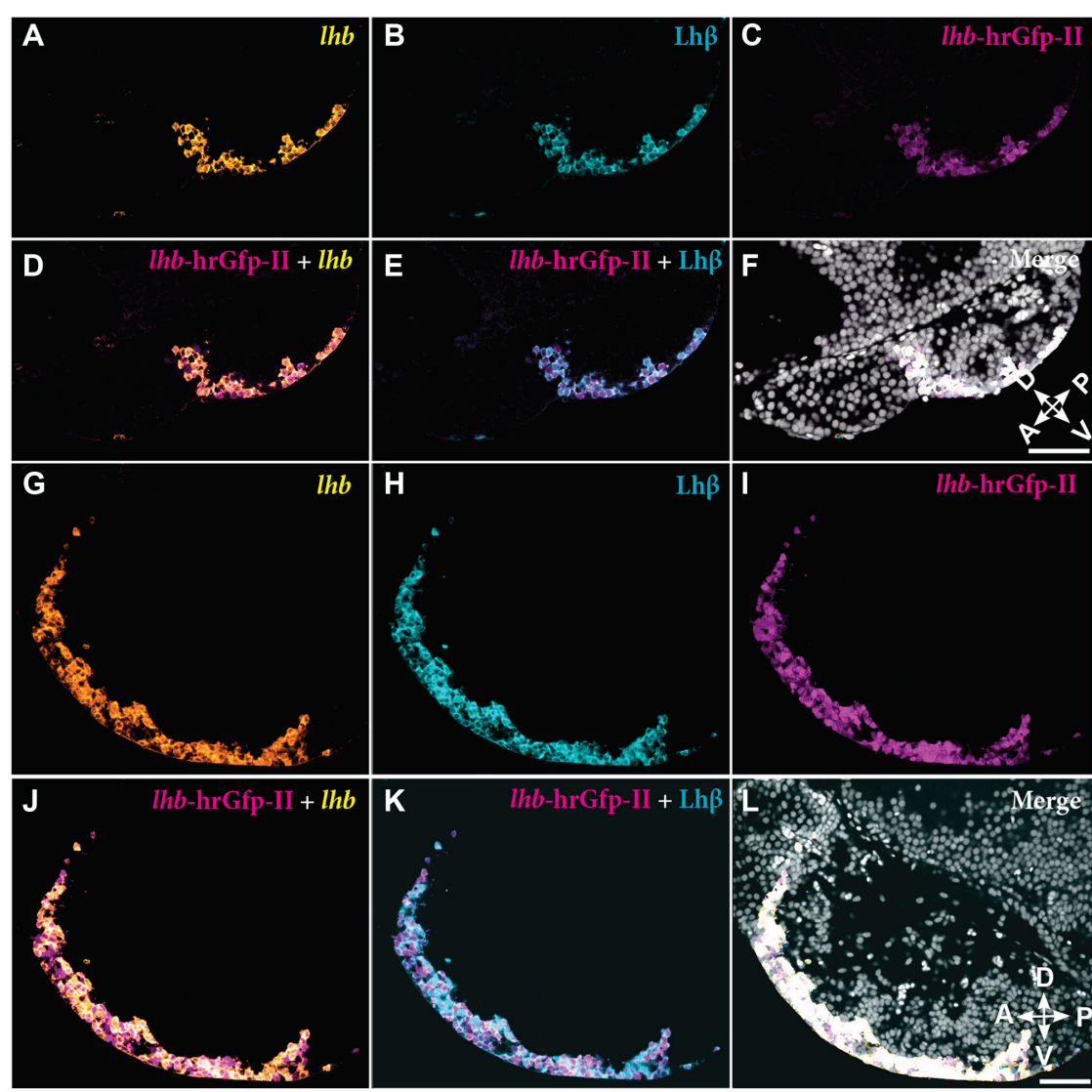

Figure 1

Confocal images of parasagittal pituitary sections from tg(Ihb-hrGfpll) juvenile (A, B, C, D, E and F) and adult $(G, H, I, J, K$ and $L)$ fish. Tissues sections are labeled for Ihb mRNA (orange, A, G) by FISH or Lh $\beta$ proteins (cyan, $B, H$ ) by IF. Endogenous hrGfpll is shown in magenta (C, I). Merged images for Ihb mRNA and endogenous hrGfpll are shown in $D$ and J. Merged images for $\operatorname{Lh} \beta$ protein and endogenous hrGfpll are shown in E and K. Merges of all labeling, together with DAPI counterstaining (gray), are shown in F and L. A, anterior; D, dorsal; $P$, posterior; $V$, ventral; scale bar: $50 \mu \mathrm{m}$. https://joe.bioscientifica.com https://doi.org/10.1530/JOE-18-0412
(C) 2019 Society for Endocrinology Published by Bioscientifica Ltd. Printed in Great Britain 


\section{Morphological analysis of the pituitary and the Lh cell population}

A significant difference between genders was observed for brain size in adults, but not for bodyweight, standard length (Supplementary Fig. 2A and B) or pituitary size or volume (Fig. 2C and D). Significant differences between juvenile and adult fish were observed for pituitary size (all three axes being almost doubled) and volume (up to 7-fold increase). Regarding pituitary size relative to brain or body size, a substantial correlation was found between pituitary length and brain length in juvenile males and females $\left(R^{2}=0.82\right.$ and $R^{2}=0.89$, respectively; Supplementary Fig. 2F, G, H, I, J, K and L), whereas no apparent correlations were found in adults.

Regarding location of Lh cells, 3D rendering of pituitaries from the $\operatorname{tg}(\mathrm{l} h b$-hrGfpII) line did not reveal any apparent differences between genders (data on males not shown) or between juveniles (Fig. 3A, B, C, D, E and Supplementary Videos 1,3) and adults (Fig. 3F, G, H, I and J and Supplementary Videos 2, 4). Most cells were localized on the ventral and lateral surfaces of the median part of the pituitary, with a few cells also in the posterior part.

There was no difference in Lh cell size between juvenile males and females, but cells were longer in adults than juveniles $(P<0.0001)$ (Fig. 4B). Cell width was significantly greater $(P<0.0001)$ in adult females than juveniles, and cells were longer and wider in adult females than adult males $(P<0.05)$. We observed that adult Lh cells increased more in length than width from juvenile to adult stages, resulting in more elongated cells in adults, often with an extension at their extremity (Fig. 4C and D).

There was no difference in the number of Lh cells or total number of pituitary cells (nuclei labeled by DAPI) in juveniles, in contrast to the clear difference seen between juveniles and adults $(P<0.001)$ and between adult males and females $(P<0.05$; Fig. 5). Although the proportion of Lh cells did not differ by gender, in adult females, there was a significant increase from juveniles $(P<0.01$; Fig. $5 C)$. This was not observed in males, presumably because of high individual (bimodal) variation in adult males.

\section{Recruitment of new Lh cells}

Time lapse recordings of dissociated pituitary cells from $\operatorname{tg}($ lhb-hrGfpII) adult males (Fig. 6A, B, C, D and Supplementary Video 5) and females (data not shown)
A

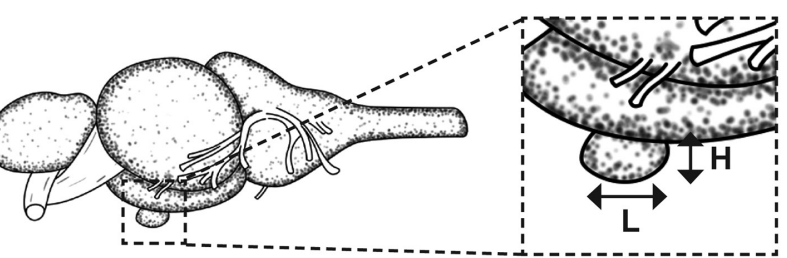

B

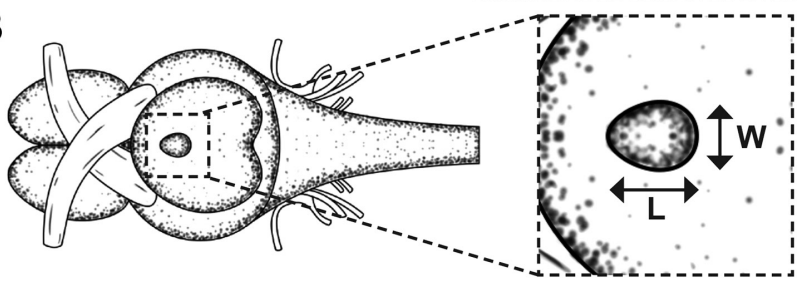

C

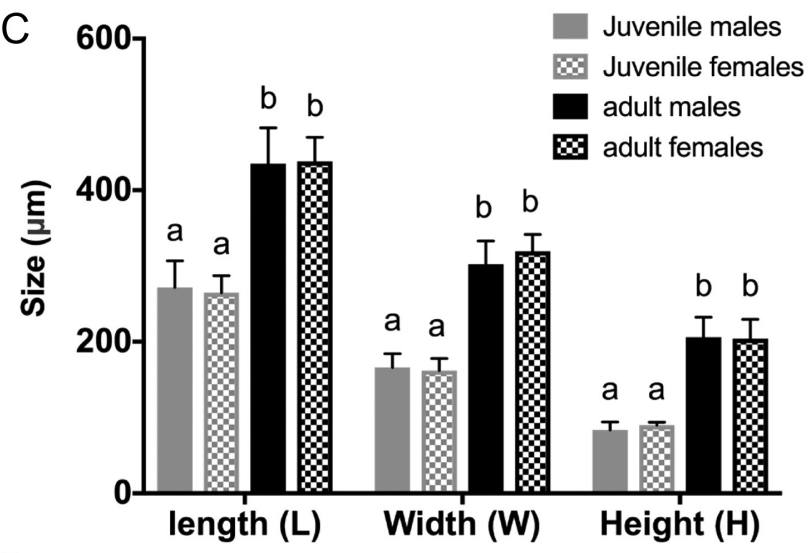

D

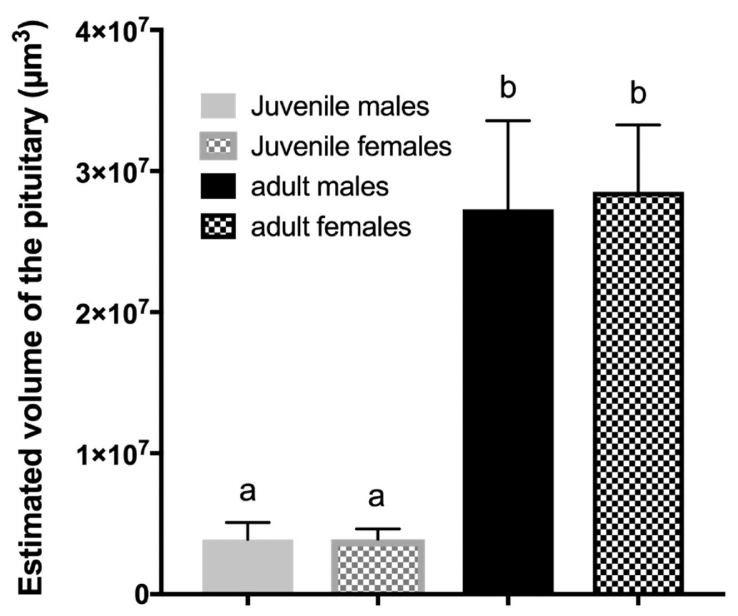

Figure 2

Measurements of the pituitary in three axes by confocal imaging. Illustrations of the lateral view (A) and ventral view (B) of the brain and pituitary of medaka showing the measurements (L: Length; W: width; $\mathrm{H}$ : height). Anterior to the left. Histograms representing (C) mean (+s.D.) of the size of the three axes (in $\mu \mathrm{m}$ ) and (D) mean (+S.D.) of the estimated volume $(\mathrm{L} \times \mathrm{W} \times \mathrm{H})$ of the pituitary from juvenile males $(n=5)$, juvenile females $(n=4)$, adult males $(n=5)$, and adult females $(n=5)$. The sizes among the four groups were significantly different $(P<0.05)$ according to a two-way ANOVA and Tukey's multiple comparison test when letters are different ( $a$ and $b$ ). 

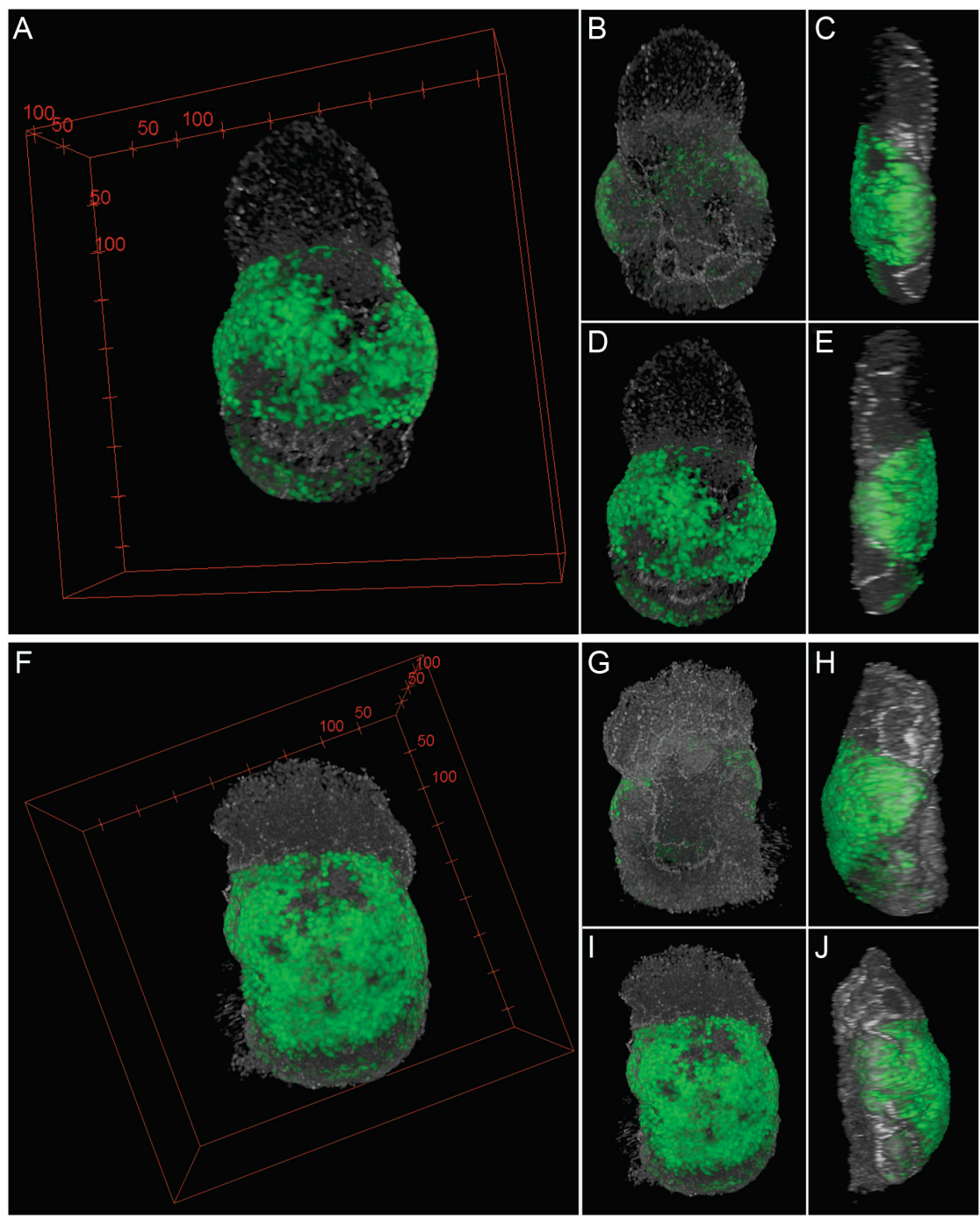

\section{Figure 3}

Snapshots of different perspectives from 3D reconstruction of whole pituitary from $\operatorname{tg}(/ h b$ hrGfpII) juvenile female medaka (A, B, C, D and E) and adult female medaka ( $F, G, H, I$ and $J)$.

Snapshots were taken from different viewpoints: ventral $(A, D, F, I)$, lateral $(C, E, H, J)$, dorsal $(B, G)$. Anterior to the top. Ventral to the left in $\mathrm{C}$ and $\mathrm{H}$, and to the right in $\mathrm{E}$ and J. Lh cells (Gfp) are in green and nuclei stained with DAPI are in gray. Scale bar in red is expressed in $\mu \mathrm{m}$.

showed some Gfp cells moving and clustering. A few Gfp-negative cells were also revealed to start expressing Gfp after $24-48 \mathrm{~h}$ in culture. The proportion of new Gfpexpressing cells varied between cultures, always with a time-dependent increase in fluorescence intensity. Using a 10x objective, simultaneous recording of ROI mean intensity for numerous cells (Fig. 6E) showed that several cells started to express Gfp between 35 and $45 \mathrm{~h}$ after plating. Some cells obtained fluorescence intensities similar to the other Gfp-expressing cells around $55 \mathrm{~h}$ after plating, only $10 \mathrm{~h}$ after starting to express Gfp. The ROI mean intensity increased linearly, but with different slopes between cells. In some cells, ROI mean intensity fluctuated with time, but never apparently disappeared. A few cells died in culture, as shown by time lapse recordings and ROI mean intensity measurements (Fig. 6B and C, and cell number 6 in Fig. 6E).

\section{Evidence for newborn Lh cells in the medaka pituitary}

After $4 \mathrm{~h}$ of BrdU treatment followed by 4 days of recovery to allow time for cell division and differentiation, we observed several BrdU-labeled cells in the brain and pituitary in both juveniles and adults (Fig. 7A, B, C and D). Some BrdU-labeled cells in the pituitary were also labeled by Gfp. The number of BrdU-Gfp cells (Fig. 7E) did not differ significantly between genders or stages. Interestingly, the number of double-labeled cells varied tremendously, with none found in some fish and others with up to 80 BrdU-Gfp-labeled cells.

\section{Location of dividing cells in the medaka pituitary}

BrdU incorporation experiments using incubation times down to $30 \mathrm{~min}$ consistently revealed BrdU-labeled cells 


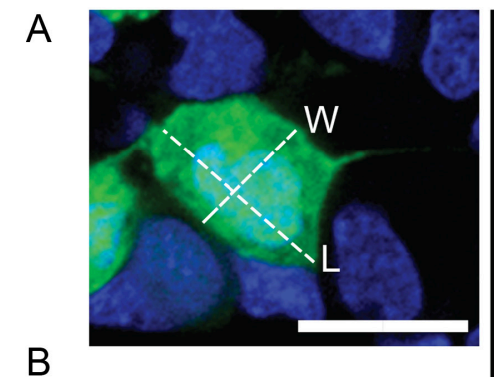

B

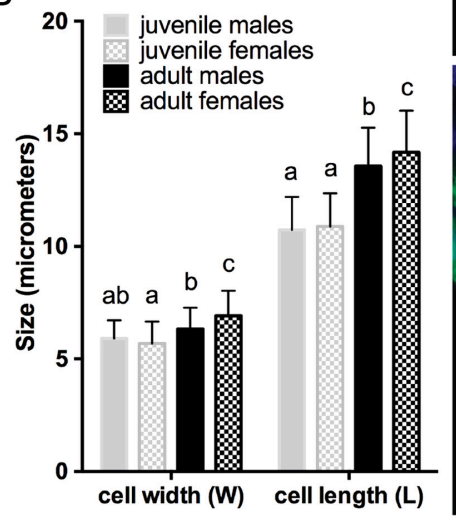

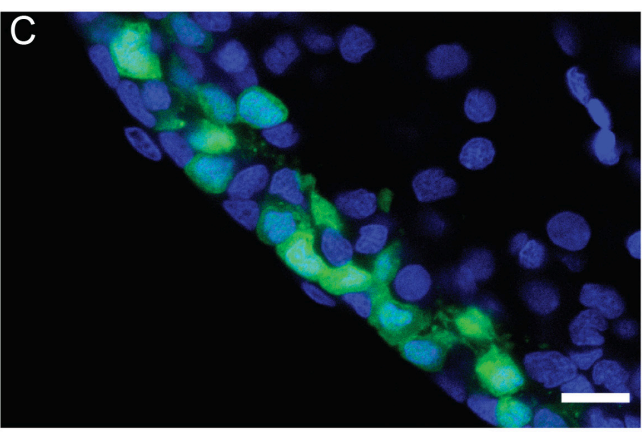

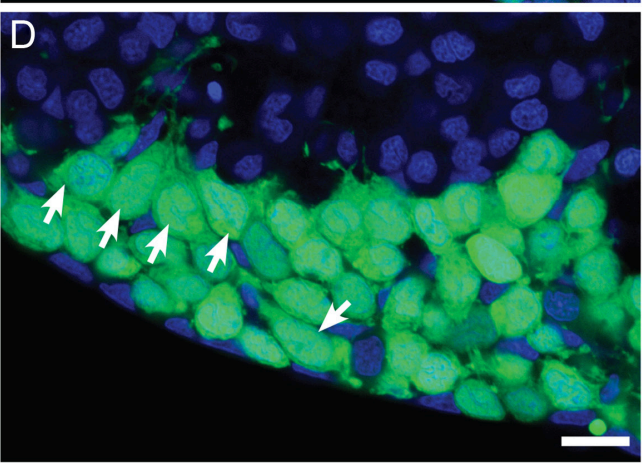

\section{Figure 4}

Morphological analysis of the Lh cells. Confocal planes of parasagittal section from juvenile $(A, C)$ and adult (D) pituitary from $\operatorname{tg}(/ h b$-hrGfpll) fish. (A) High magnification showing the two axes used to measure the cell size ( $L$ : length, the longest size; W: width). (B) Histogram representing mean (+S.D.) of two cell size parameters as shown in $A$, of the 15 largest cells from $5 \operatorname{tg}(/ h b$-hrGfpII) fish, from juvenile and adult fish of both genders. The sizes among four groups were significantly different $(P<0.05)$ using two-way ANOVA with Tukey's multiple comparison test when letters are different ( $a, b$ and $c)$. (D) Arrows indicate elongated cells observed in adult. Scale bars: $10 \mu \mathrm{m}$. in all parts of the pituitary (Fig. 8A and B). A number of doublets (i.e., two closely situated cells labeled with BrdU), suggested recently divided cells. The presence of cells throughout the pituitary labeled by PCNA, an essential protein for DNA replication during the cell cycle, confirmed active cell division (Supplementary Fig. 3).

\section{Mitosis of Lh cells in medaka pituitary}

BrdU exposure always resulted in double-labeled cells (Gfp and BrdU), regardless of incubation time. Occasional observation of double-labeled cells in anaphase (Fig. 8C, D and E) or PCNA-labeled Gfp cells (Fig. 8F, G and H) clearly demonstrated that Gfp cells might undergo mitosis.

\section{Lh cells are not multipotent stem cells}

We found several cells in brain and pituitary that were positive for Sox2, a marker for multipotent stem cells (cells with the ability to self-renew for long periods of time and differentiate into various cell types) in mammals (Mollard et al. 2012) and medaka (Alunni et al. 2010, Lust \& Wittbrodt 2018) (Fig. 8I, J, K, L and M). However, Sox2labeled cells were mostly located in the dorsal pituitary, close to the pars nervosa, with only a few cells scattered
A

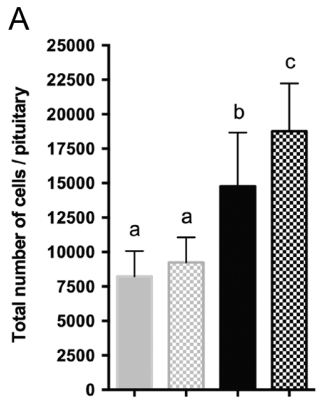

B

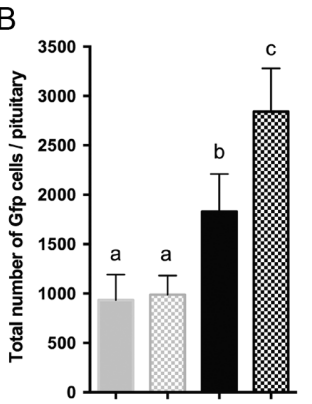

C

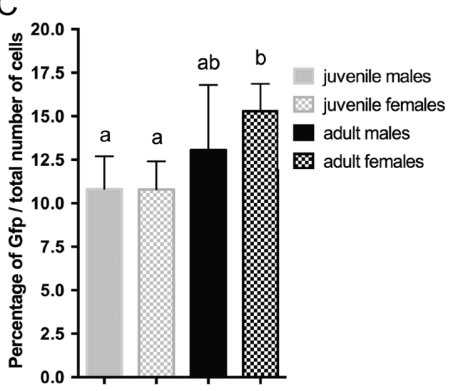

Figure 5

Cell counting for the four different groups of fish: juvenile males $(n=8)$ and females $(n=9)$, and adult males $(n=9)$ and females $(n=7)$. Cells were counted using the process described in Supplementary Fig. 1, from confocal images of $\operatorname{tg}(/ h b$-hrGfpll) whole pituitaries. (A) Mean (+S.D.) of the total number of cells in the pituitary. (B) Mean (+s.D.) of the number of Gfp cells in the pituitary. (C) Mean (+s.D.) of the percentage of Gfp cells related to the total number of cells in the pituitary. For each graph, one-way ANOVA with Tukey's multiple comparison test revealed significant differences $(P<0.05)$ when letters are different ( $a, b$ and $c)$. 

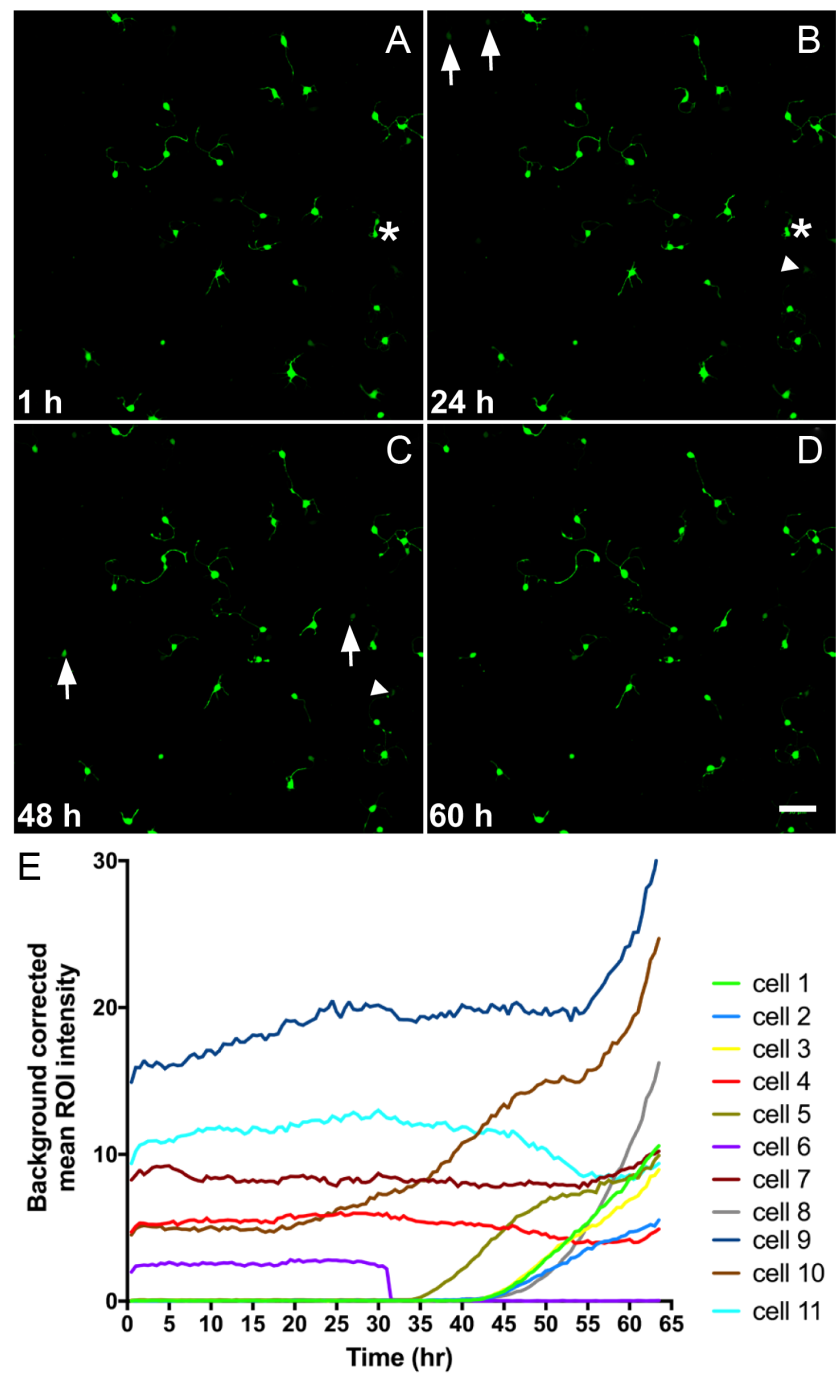

Figure 6

(A, B, C and D) Time lapse of confocal images of primary pituitary cell culture from $\operatorname{tg}(/ h b$-hrGfpII) adult male pituitaries (snapshots extracted from Supplementary Video 5) imaged with $25 \times$ objective. Arrows show the location of the new cells expressing Gfp. The star shows two cells clustering and the arrow head shows a cell disappearing. Scale bars: $50 \mu \mathrm{m}$. (E) Background corrected mean ROI intensity for 11 different cells over time, from another cell culture imaged with a 10× objective.

throughout the pituitary. We never observed Gfp in Sox2labeled cells (Fig. 8N, O and P).

\section{Effects of estradiol on pituitary and Lh-specific cell proliferation}

Two days of estradiol treatment (diluted in EtOH) had no significant effect on pituitary cell proliferation, in either males or females (Fig. 9A and B). However, after 6 days of estradiol treatment, the total number of BrdUlabeled cells $(P<0.0001)$, the number of double-labeled
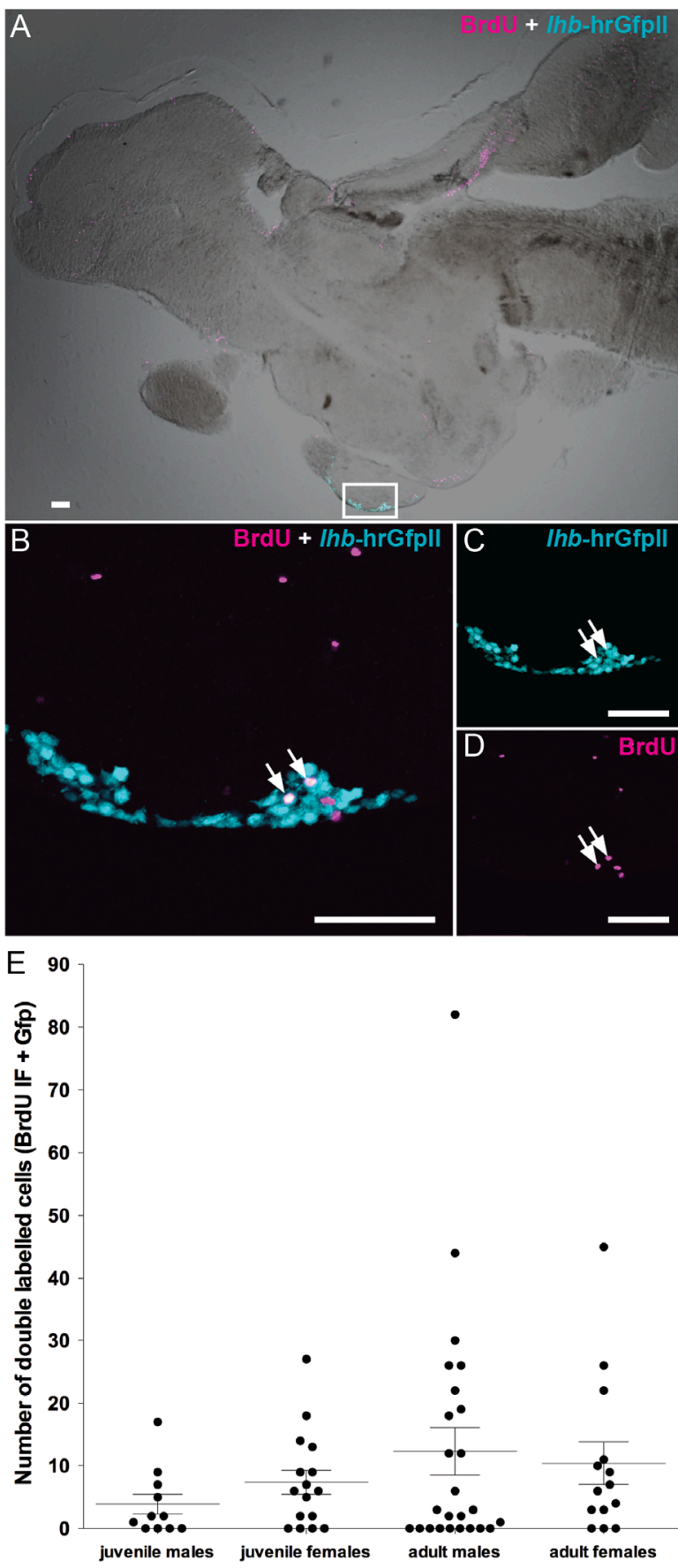

Figure 7

Cell proliferation in the pituitary. (A) Confocal plane of brain and pituitary from $\operatorname{tg}(/ h b$-hrGfpll) adult female medaka with BrdU IF labeling in magenta and Lh cells (Gfp labeling) in cyan, superimposed to a transmitted light microscope image in order to view the anatomy. (B, C and D) Confocal magnification of the selected region shown in A. Arrows show cells that are double labeled with Gfp and BrdU IF. Anterior to the left. Scale bars: $50 \mu \mathrm{m}$. (E) Plotted graph presenting the number of double-labeled cells: Gfp and BrdU IF in the pituitary. One dot represents one individual and horizontal bars represent the mean (largest one in the middle) and \pm S.E.M. No significant differences between gender or stages according to one-way ANOVA followed by Kruskal-Wallis multiple comparison test. 


\begin{tabular}{l|l|l|r|}
$\begin{array}{l}\text { Journal of } \\
\text { Endocrinology }\end{array}$ & R Fontaine et al. & Plasticity of Lh cells in medaka & $\mathbf{2 4 0 : 2}$
\end{tabular}
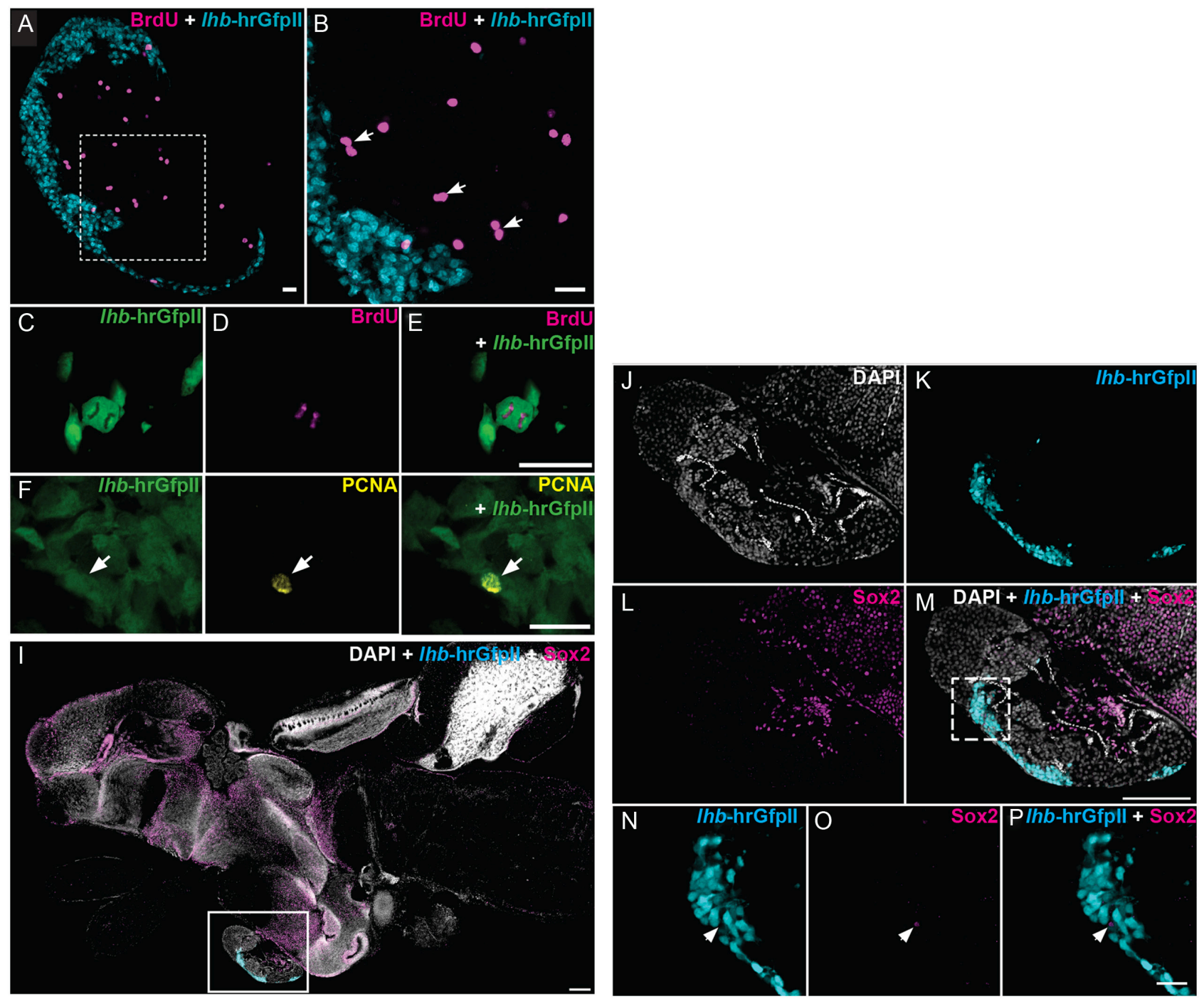

\section{Figure 8}

Identification of some Lh cell progenitors. (A and B) Projection of 15 confocal Z-plans (1 $\mu$ m step between each picture) of a parasagittal section of medaka brain-pituitary from $\operatorname{tg}(/ \mathrm{hb}$-hrGfpll) adult male (cyan) incubated with $1 \mathrm{mM}$ BrdU for $1 \mathrm{~h}$, fixed immediately after treatment and then labeled with BrdU (magenta) for IF. (B) High magnification of the selected area shown in A, with arrows showing doublets: two cells close to each other that could represent sister cells. Anterior to the left. (C, D and E) Confocal plan of parasagittal section of medaka brain-pituitary from tg(Ihb-hrGfpll) adult male (green). Fish have been incubated with BrdU $1 \mathrm{mM}$ for $4 \mathrm{~h}$, fixed immediately after treatment and then labeled with BrdU (magenta) for IF, showing an Lh cell in the anaphase of mitosis. ( $\mathrm{F}, \mathrm{G}$ and $\mathrm{H}$ ) Confocal plan of parasagittal section of medaka brain-pituitary from $\operatorname{tg}(\mathrm{Ihb}$-hrGfpll) adult medaka male (green) labeled with PCNA (yellow) for IF, with arrows showing a cell labeled with both Gfp and PCNA. Scale bars: 20 m. (I, J, K, L, M, N, O and P) confocal images of parasagittal section of medaka brain-pituitary from $\operatorname{tg}(I \mathrm{hb}$-hrGfplI) adult male (cyan) labeled with Sox2 (magenta) for IF. Scale bars: $100 \mu \mathrm{m}$. (U, $\mathrm{K}, \mathrm{L}$ and M) Magnification of the pituitary shown in I. ( $\mathrm{N}, \mathrm{O}$ and P) Magnification of the dashed square zone shown in P from another confocal plan, showing the Lh cell population and a peripheral Sox2-positive cell. Scale bar: $20 \mu \mathrm{m}$.

cells (BrdU and Gfp) $(P<0.001)$ and the proportion of double-labeled cells $(P<0.0001)$ increased in males. Double-labeled cells represented about $50 \%$ of the total number of BrdU-positive cells in the pituitary of males. In contrast, only the total number of BrdU-labeled cells significantly increased $(P<0.01)$ after 6 days of treatment in females. Interestingly, by diluting estradiol in DMSO instead of EtOH, similar results were obtained for males, but no significant change was observed for females (Supplementary Fig. 4). Our results indicate that EtOH could be a better solvent for estradiol than DMSO.

\section{Effects of estradiol on Ihb expression in the pituitary}

Using a combination of rna18s and $r p l 7$ as reference genes, a significant decrease in the level of $\ln b(P<0.05)$ and https://joe.bioscientifica.com https://doi.org/10.1530/JOE-18-0412
(C) 2019 Society for Endocrinology Published by Bioscientifica Ltd.
Printed in Great Britain 

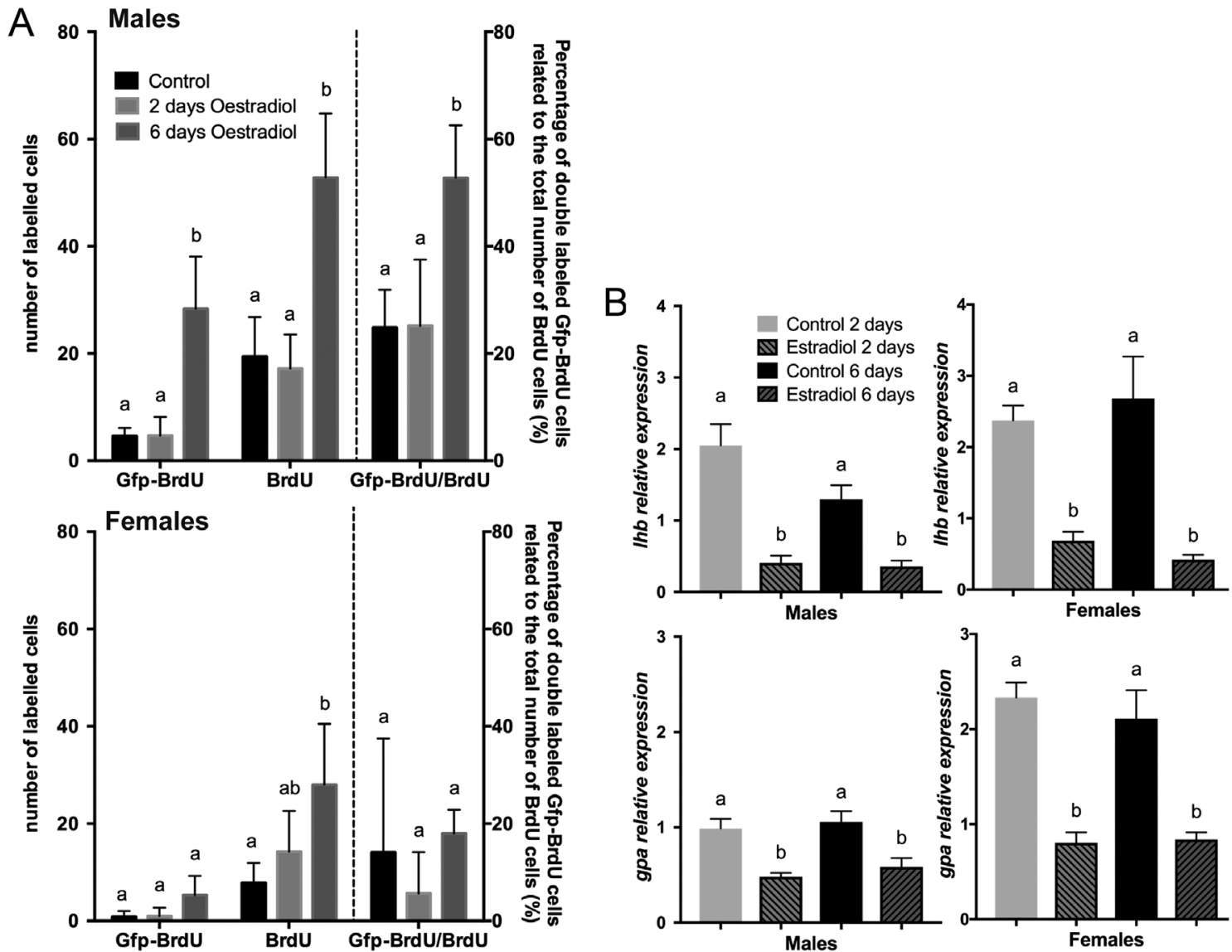

Figure 9

(A) Effect of estradiol on cell proliferation in $\operatorname{tg}(\mathrm{lhb}$-hrGfpll) adult medaka. Histograms represent the mean (+s.D.) of the number of double-labeled cells (Gfp and BrdU IF), the total number of BrdU-labeled cells in the pituitary on the left axis, and the percentage of double-labeled cells in relation to the total number of BrdU-labeled cells on the right axis, according to different estradiol treatment in males and females. Fish were treated for either 2 ( 5 females and six males) or 6 ( 6 females and six males) days with estradiol or with EtOH only for 6 days (control; six females and six males). The number of double-labeled cells among the four groups were significantly different $(P<0.05)$ using two-way ANOVA with Tukey's multiple comparison test when letters are different ( $\mathrm{a}$ and b). (B) Effect of estradiol on $\mathrm{lhb}$ and gpa expression levels in adult medaka. Fish were treated for either 2 or 6 days with estradiol or with EtOH only (7 fish of each gender in each group). Means (+S.E.M.) of the expression levels of Ihb and gpa have been normalized with the expression level of the combination of $r n a 18 \mathrm{~s}$ and $r$ pl7. Significant differences between the four treatment groups $(P<0.05)$ are shown when letters are different $(a$ and $b$ ) using one-way ANOVA with Tukey's multiple comparison test.

gpa $(P<0.05)$ mRNA was found in both male and female pituitaries after both 2 and 6 days of estradiol treatment (Fig. 9C).

\section{Lh cells express steroid receptors}

RNA-seq data from FACS-sorted Gfp cells from juvenile (data not shown) and adult females showed expression of the three Ers known in medaka (Supplementary Fig. 5A); esr1 (Er $\alpha$; ENSORLG00000014514), esr2a (Er $\beta 1 ; \quad$ ENSORLG00000017721), esr2b (Er $\beta 2 ;$ ENSORLG00000018012), with relatively high levels for esr 1 and $e s r 2 b$. ISH revealed similar localization of esr 1 and esr $2 b$ in the brains of adult males and females (Supplementary Fig. 6). Both receptors were also expressed in the pituitary, especially the region where Lh cells are located. Double FISH confirmed the expression of these two receptors in some of the Lh cells in both genders, although they were also expressed in other cells (Fig. 10).

\section{Lh cells express aromatase}

RNA-seq data revealed expression in Lh cells of the brain form of aromatase, cyp19a1b (ENSORLG00000005548), but not cyp19a1a (ENSORLG00000002949) (Supplementary Fig. 5B). FISH for cyp19a1b confirmed the presence of aromatase in different brain regions (Fig. 11), as well as the pituitary. Double FISH for $l h b$ and $c y p 19 a 1 b$ confirmed the RNA-seq observations, showing that most Lh cells also express cyp19a1b. 


\begin{tabular}{l|l|l|r|r|}
$\begin{array}{l}\text { Journal of } \\
\text { Endocrinology }\end{array}$ & R Fontaine et al. & Plasticity of Lh cells in medaka & $\mathbf{2 4 0 : 2}$ & $\mathbf{3 7 1}$ \\
\hline
\end{tabular}

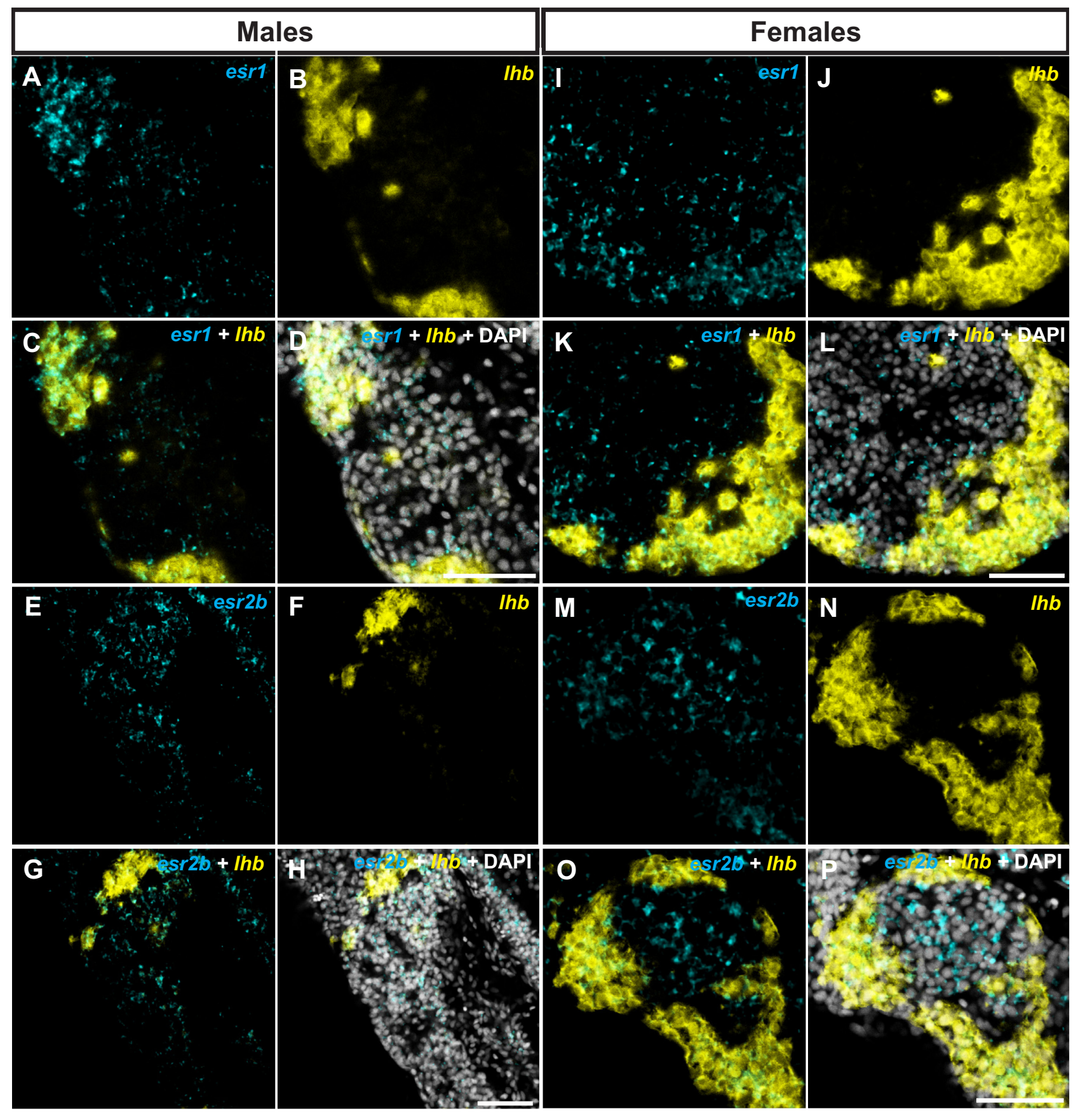

\section{Figure 10}

Expression of the estrogen receptors esr 1 (Er $\alpha$ ) and esr2b (Er $\beta 2)$ in the Lh cells. Confocal planes of parasagittal sections from brain and pituitary from adult males (A, B, C, D, E, F, G and H) and females (I, J, K, L, M, N, O and P) wild-type medaka. Tissues have been labeled with double-color FISH for Ihb (yellow) and either esr1 (blue, A, B, C, D and I, J, K, L) or esr2b (blue, E, F, G, H and M, N, O, P). Anterior to the left. Scale bars: $50 \mu \mathrm{m}$.

\section{Discussion}

Lh is a key player in the BPG axis, controlling reproductive function. However, little is known about Lh cells themselves and the population they form in the pituitary. In this study, we used 2-month-old juveniles and 6-month-old adults of the $\operatorname{tg}(\mathrm{lhb}$-hrGfpII) line of medaka (Hildahl et al. 2012) to investigate developmental changes in Lh-producing gonadotropes during puberty. We demonstrate that Gfp is a reliable reporter for both lhb mRNA and $\operatorname{Lh} \beta$ protein expression, in juveniles and adults, thus showing the usefulness of this line to visualize 

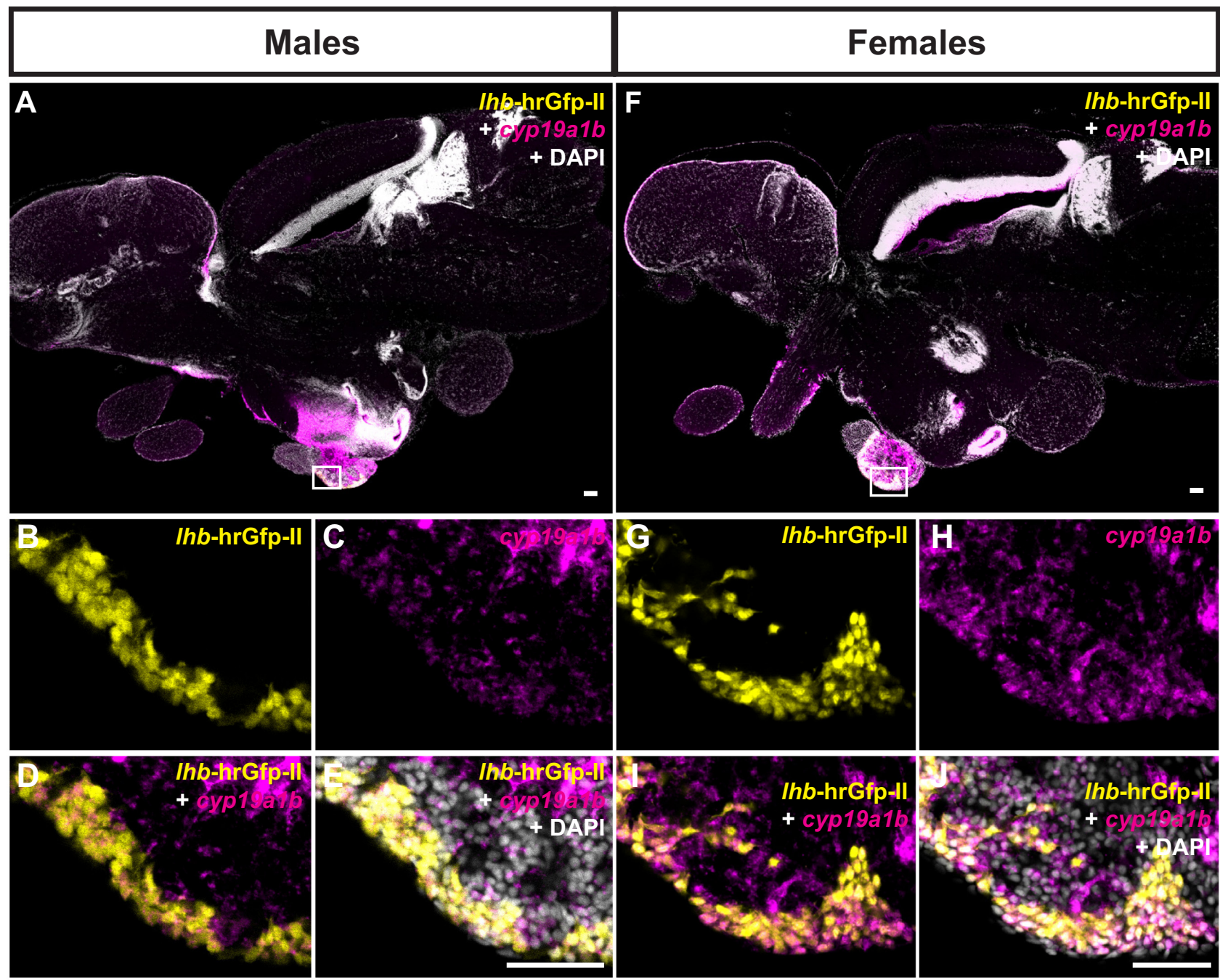

\section{Figure 11}

Expression of the aromatase cyp19a1b in the Lh cells. Confocal planes of parasagittal sections from brain and pituitary from adult males (A, B, C, D and E) and females (F, G, H, I and J) tg(Ihb-hrGfplI) medaka. Endogenous Gfp is shown in yellow and cyp19a1b expression revealed by FISH is shown in magenta, and nuclear DAPI staining is shown in gray. (B, C, D and E) show higher magnifications of the pituitary shown in A and G, H, I, J show higher magnifications of the pituitary shown in F. Anterior to the left. Scale bars: $50 \mu \mathrm{m}$.

and localize all Lh-producing (Gfp) cells, referred to as Lh cells, following the definition of endocrine cells used by Pogoda \& Hammerschmidt (2009).

We then studied the morphology of the whole pituitary and showed that it grows from juvenile to adult stage, without any gender difference. This is not surprising, as the brains of fish have previously been shown to keep growing, even during adulthood (Lindsey $\&$ Tropepe 2006). Moreover, several studies have already reported allometric growth of different organs in relation to body size during development (Osse \& Boogaart 1995, Van Snik et al. 1997, Huysentruyt et al. 2009). In medaka, we observed a correlation between pituitary length and brain size in juveniles, but this was not the case in adults.
No correlation was found between size or volume of the pituitary and fish length or weight in adults, suggesting that factors other than those for normal fish growth participate in control of pituitary growth.

Lh cells are located in the ventral and lateral surfaces of the median part (proximal pars distalis, PPD), and a few cells in the posterior part (pars intermedia, PI) of the pituitary in both juvenile and adult medaka, concurs with reports from zebrafish (So et al. 2005), tilapia (Oreochromis niloticus) (Golan et al. 2014) and Chinese sturgeon (Acipenser sinensis) (Cao et al. 2009). However, this distribution differs from that observed in European hake (Merluccius merluccius) (Candelma et al. 2017) and European eel (Schmitz et al. 2005), where Lh cells are 
distributed throughout the PPD. Although we did not observe any differences between genders, there was a higher absolute number and a higher proportion of Lh cells, in combination with larger Lh cells, in adult females than juveniles. The increased size of Lh cells in adults could be explained by the fact that, at least in females, Lh cells are known to store a considerable quantity of hormone-containing vesicles until the Lh surge around ovulation (Zohar 1988, Karigo et al. 2012). The increased number of cells could be explained by the necessity to increase hormone production in order to maintain a high concentration in the growing target tissues. Indeed, the pituitary gland must adapt the proportion of all endocrine cell types to meet different hormonal demands throughout the lifecycle of the animal.

We then looked for the origin of the new Lh cells and demonstrated that in dispersed pituitary cell cultures, some cells of unknown phenotype are able to start producing $l \mathrm{hb}$. This clearly indicates recruitment of existing pituitary cells for production of $l \mathrm{hb}$. Unfortunately, we could not identify the cell type before it started to produce Gfp. Further investigations are necessary to understand whether the new $l h b$-producing cells come from phenotypic conversion of differentiated cells (transdifferentiation as shown for mammotropes and somatotropes in the mammalian pituitary (Porter et al. 1991)), differentiation of progenitor cells in the pituitary or activation of quiescent Lh cells. Interestingly, the number of cells starting to express Gfp varied between cell cultures, and several of the new Gfpexpressing cells appeared simultaneously. We assume that cell density, the presence of paracrine factors in culture or the physiological status of the donor fish could influence the recruitment of existing cells for the expression of $l \mathrm{hb}$. So far, we have not been able to determine exactly what induces this phenomenon, but Gnrh and sex steroids may be good candidates for further studies.

In the mammalian brain, it has been demonstrated that, even with high concentrations and direct cardiac perfusion, BrdU incorporation during DNA repair is insufficient to label any damaged or apoptotic cells (Bauer \& Patterson 2005). BrdU is therefore a useful marker for revealing the location and number of recently divided and currently dividing cells. Our experiments, using $4 \mathrm{~h}$ of incubation with BrdU followed by 4 days of recovery in both juveniles and adults, revealed some cells had been double-labeled with both Gfp and BrdU. The G1 and the $S$ phases are the longest of the cell cycle (Borrell \& Calegari 2014) and last only a few hours (Cameron \& Greulich 1963, Hahn et al. 2009, Turrero Garcia et al. 2016, Akle et al. 2017). Therefore, by waiting 4 days after the integration of BrdU by the cells in S phase, these cells should have completed mitosis. Consequently, our results suggest that new Lh cells arise from mitotic activity, both in juveniles and adults.

Such a sustained cell proliferation could be achieved either by maintenance of undifferentiated progenitors (Chapouton \& Godinho 2010) or by mitosis of existing gonadotrope cells. It has previously been demonstrated that anterior pituitary cells of mammals retain the capacity to divide (Taniguchi et al. 2002). Mitosis has been reported in prolactin and LH cells, contributing to their proliferation in rats (Sakuma et al. 1984, Takahashi 1995). Here, fish killed immediately after short pulses of BrdU always revealed some double-labeled (BrdU-Gfp) cells suggesting that Lh cells were dividing. We also observed some Lh cells in anaphase, as well as some double-labeled cells with Gfp and PCNA, confirming that Lh cells are able to divide in the medaka pituitary.

The existence of specific niches of multipotent progenitor cells has been reported in the adult mammalian pituitary. Indeed, Sox2, an important multipotent progenitor cell marker (Fauquier et al. 2008b, Kelberman et al. 2009), has been used to localize stem cells in a concentrated layer lining the mammalian pituitary cleft, the intraglandular structure at the border of the neurohypophysis and adenohypophysis, with a few additional cells in the pituitary (Fauquier et al. 2008a,b). In medaka, Sox 2 has also been shown to be a multipotent progenitor cell marker in the brain (Alunni et al. 2010) and retina (Lust \& Wittbrodt 2018). Here, we observed Sox2-positive cells in brain regions previously shown to express Sox 2 in zebrafish (Germana et al. 2011) and in the dorsal part of the medaka pituitary. In the pituitary, Sox2-positive cells are located in close proximity to the pars nervosa, where the neuronal projections from the hypothalamus enter the pituitary, with very few extra cells scattered throughout the pituitary. Therefore, this study reveals the location of potentially multipotent stem cells in the adult fish pituitary, in a region equivalent to that identified for mammals. Although a significant number of dividing (PCNA-positive) cells were also Sox2 positive in zebrafish and medaka brain (Alunni et al. 2010, Diotel et al. 2013) and also differentiated Lh cells retain the capacity to divide in medaka pituitary, and none of the Lh cells expressed Sox2, suggesting that Lh cells are probably not multipotent progenitor cells.

Although we could have expected a higher degree of Lh cell proliferation in juvenile fish that are in the fastest growth phase, we did not observe any significant differences in the capacity of Lh cells to proliferate in the 
pituitary, either between juveniles and adults, or between genders. However, in all groups, we found individuals without newborn cells and others with numerous newborn Lh cells, suggesting Lh cell proliferation is controlled by one or several biological factors. Estrogens have been shown to affect brain development and to modulate embryonic and adult neurogenesis (Martinez-Cerdeno et al. 2006, Mouriec et al. 2008, Barha et al. 2009, Kah et al. 2009, Diotel et al. 2013, Coumailleau et al. 2015). To the best of our knowledge, nothing is known about the effect of estradiol on cell proliferation in fish pituitary. In mammals, however, several studies have investigated the role of sex steroids on LH cell proliferation. Indeed, mitotic LH cells drastically increase after castration in male rats (Sakuma et al. 1984), and ovariectomy in female rats (Smith \& Keefer 1982), suggesting a negative effect of steroids on LH cell proliferation. In contrast, our results revealed a positive effect of estradiol on cell proliferation in medaka. Interestingly, estradiol had a stronger effect in males than in females. This is possibly due to higher background level of estradiol in females (Bhatta et al. 2012), and therefore, the estradiol treatment is less obvious in females.

Although it has mostly been reported that estradiol treatment increases lhb and gpa synthesis in fish (Yaron et al. 2003, Li et al. 2018), our results show a clear decrease of both $l h b$ and gpa mRNA levels following estradiol treatment, in both genders. To the best of our knowledge, the only study where a negative effect of estradiol on lhb and gpa synthesis in fish has been reported was also from medaka (Zhang et al. 2008). The authors showed a decrease in mRNA levels for $l h b$ and $g p a$, using even lower estradiol concentrations. Several studies have shown that estradiol could decrease $l h b$ synthesis in mammals (Liu \& Jackson 1977, Di Gregorio \& Nett 1995). Indeed, it has been found that estradiol has a bimodal effect on lhb and gpa synthesis, mostly depending on the reproductive stage of the animal (Lindzey et al. 2006). The decrease in $l h b$ and gpa expression levels after estradiol treatment shown in our studies can be explained by the fact that estradiol increases Lh cell proliferation, as transcription of many genes is thought to be silenced during mitosis (Taylor 1960, Prescott \& Bender 1962, Parsons \& Spencer 1997).

In addition to demonstrating an effect of estradiol on Lh cell proliferation and that Lh cells have the capacity to divide, we also showed that Lh cells express estrogen receptors, suggesting a direct effect of estradiol. Lh cells have been shown to express esr $2 b$ in zebrafish females (Li et al. 2018). Our results show, in agreement with those of
Zempo et al. (2013), that several brain areas express Esr in medaka. Whereas RNA-seq has been done on whole Lh cell populations in the pituitary, thus masking heterogeneity in the cell population, FISH revealed that some, but not all, Lh cells express esr 1 and esr $2 b$. Additionally, our results showed that Lh cells are not the only pituitary cells to possess Ers; this fits with the fact that proliferation of cell types in the pituitary, other than Lh cells, is activated by estradiol.

Androgens can be converted into estrogens (Simpson \& Davis 2001) by aromatase. Fish are unique among vertebrates as aromatase B (cyp19a1b) is strongly expressed in the adult brain, especially in some progenitor cells (Noctor et al. 2001, Pellegrini et al. 2007, Lam et al. 2009, Marz et al. 2010, Rothenaigner et al. 2011). Our results show substantial aromatase expression in medaka brain and pituitary, in agreement with a previous publication (Okubo et al. 2011). The high aromatase expression suggests that estradiol can be produced in the pituitary from androgens. The positive effect of estradiol on $l h b$ expression has been shown across different species and also for testosterone after its aromatization to estradiol (Yaron et al. 2003). Thus, control of pituitary Lh cell proliferation could be via estrogen produced by the gonads or locally in the pituitary.

In conclusion, our study provides information on the Lh cell population and its high degree of plasticity in the medaka pituitary. We demonstrate that the pituitary and Lh cell population evolve between juvenile and adult stages, with new Lh-producing cells arising due to both mitosis of Lh cells and recruitment of existing cells for the production of $l h b$. Our findings offer insights into the possible role of estradiol in facilitating pituitary cell proliferation, including Lh cells. In addition, Lh cells that have the capacity to divide also express esr1, esr $2 b$ and cyp19a1b, suggesting a direct effect of estrogens and androgens on Lh cell proliferation. Although this study has focused on Lh cells, a similar study conducted on the Fsh cell population could further elucidate how plasticity of gonadotrope cells is controlled.

\section{Supplementary data}

This is linked to the online version of the paper at https://doi.org/10.1530/ JOE-18-0412.

\section{Declaration of interest}

The authors declare that there is no conflict of interest that could be perceived as prejudicing the impartiality of the research reported. (c) 2019 Society for Endocrinology Published by Bioscientifica Ltd. Printed in Great Britain 


\section{Funding}

This work was funded by the Norwegian University of Life Sciences and by the Research Council of Norway, grant numbers 244461 and 243811 (Aquaculture program) and 248828 (Digital Life program).

\section{Ethical approval}

Animal experiments were performed according to recommendations on the care and welfare of research animals at the Norwegian University of Life Sciences, with specific approval from the Norwegian Food Safety Authority (FOTS ID 8596).

\section{Authors' contribution statement}

$\mathrm{R} \mathrm{F}$ and $\mathrm{E} \mathrm{A} \mathrm{W}$ conducted the experiments. R F, E A W, F A W and $\mathrm{K} \mathrm{H}$ conceived the research and analyzed the data. R F, E A W and F A W wrote the manuscript, with input from the other authors.

\section{Acknowledgements}

The authors are grateful to Dr Rasoul Nourizadeh-Lillabadi for the $\mathrm{qPCR}$, Susann Burow for providing the medaka Lh $\beta$ antibody, Dr Karine Rizzoti for providing the Sox2 antibody and Dr Kataaki Okubo for providing the plasmid to prepare the cypa19a1b RNA probe. They also thank Dr Lucy Robertson for English editing, Lourdes Carreon G Tan for fish facility maintenance and Anthony Peltier for illustrations.

\section{References}

Ager-Wick E, Henkel CV, Haug TM \& Weltzien FA 2014 Using normalization to resolve RNA-Seq biases caused by amplification from minimal input. Physiological Genomics 46 808-820. (https://doi. org/10.1152/physiolgenomics.00196.2013)

Ager-Wick E, Hodne K, Fontaine R, von Krogh K, Haug TM \& Weltzien FA 2018 Preparation of a high-quality primary cell culture from fish pituitaries. Journal of Visualized Experiments 138. (https://doi. $\operatorname{org} / 10.3791 / 58159)$

Akle V, Stankiewicz AJ, Kharchenko V, Yu L, Kharchenko PV \& Zhdanova IV 2017 Circadian kinetics of cell cycle progression in adult neurogenic niches of a diurnal vertebrate. Journal of Neuroscience $\mathbf{3 7}$ 1900-1909. (https://doi.org/10.1523/JNEUROSCI.3222-16.2017)

Alunni A, Hermel JM, Heuze A, Bourrat F, Jamen F \& Joly JS 2010 Evidence for neural stem cells in the medaka optic tectum proliferation zones. Developmental Neurobiology 70 693-713. (https:// doi.org/10.1002/dneu.20799)

Barha CK, Lieblich SE \& Galea LAM 2009 Different forms of oestrogen rapidly upregulate cell proliferation in the dentate gyrus of adult female rats. Journal of Neuroendocrinology 21 155-166. (https://doi. org/10.1111/j.1365-2826.2008.01809.x)

Bauer S \& Patterson PH 2005 The cell cycle-apoptosis connection revisited in the adult brain. Journal of Cell Biology 171 641-650. (https://doi.org/10.1083/jcb.200505072)

Bhatta S, Iwai T, Miura C, Higuchi M, Shimizu-Yamaguchi S, Fukada H \& Miura T 2012 Gonads directly regulate growth in teleosts. PNAS 109 11408-11412. (https://doi.org/10.1073/pnas.1118704109)

Borrell V \& Calegari F 2014 Mechanisms of brain evolution: regulation of neural progenitor cell diversity and cell cycle length. Neuroscience Research 86 14-24. (https://doi.org/10.1016/j.neures.2014.04.004)
Burow S, Fontaine R, Von Krogh K, Mayer I, Nourizadeh-Lillabadi R, Hollander-Cohen L, Cohen Y, Shpilman M, Levavi-Sivan B \& Weltzien FA 2018 Medaka follicle-stimulating hormone (Fsh) and luteinizing hormone (Lh): developmental profiles of pituitary protein and gene expression levels. General and Comparative Endocrinology [epub].

Cameron IL \& Greulich RC 1963 Evidence for an essentially constant duration of DNA synthesis in renewing epithelia of the adult mouse. Journal of Cell Biology 18 31-40. (https://doi.org/10.1083/jcb.18.1.31)

Candelma M, Fontaine R, Colella S, Santojanni A, Weltzien FA \& Carnevali O 2017 Gonadotropin characterization, localization and expression in the European hake (Merluccius merluccius). Reproduction 153 123-132. (https://doi.org/10.1530/REP-16-0377)

Cao H, Zhou L, Zhang YZ, Wei QW, Chen XH \& Gui JF 2009 Molecular characterization of Chinese sturgeon gonadotropins and cellular distribution in pituitaries of mature and immature individuals. Molecular and Cellular Endocrinology 303 34-42. (https://doi. org/10.1016/j.mce.2009.01.015)

Carpenter AE, Jones TR, Lamprecht MR, Clarke C, Kang IH, Friman O, Guertin DA, Chang JH, Lindquist RA, Moffat J, et al. CellProfiler: image analysis software for identifying and quantifying cell phenotypes. Genome Biology 20067 R100. (https://doi.org/10.1186/ gb-2006-7-10-r100)

Cavaco JEB, van Baal J, van Dijk W, Hassing GAM, Goos HJ \& Schulz RW 2001 Steroid hormones stimulate gonadotrophs in juvenile male African catfish (Clarias gariepinus). Biology of Reproduction 64 1358-1365. (https://doi.org/10.1095/biolreprod64.5.1358)

Chapouton P \& Godinho L 2010 Neurogenesis. Methods in Cell Biology 100 73-126. (https://doi.org/10.1016/B978-0-12-384892-5.00004-9)

Coumailleau P, Pellegrini E, Adrio F, Diotel N, Cano-Nicolau J, Nasri A, Vaillant C \& Kah O 2015 Aromatase, estrogen receptors and brain development in fish and amphibians. Biochimica et Biophysica Acta 1849 152-162. (https://doi.org/10.1016/j.bbagrm.2014.07.002)

Di Gregorio GB \& Nett TM 1995 Estradiol and progesterone influence the synthesis of gonadotropins in the absence of gonadotropin-releasing hormone in the ewe. Biology of Reproduction 53 166-172. (https://doi. org/10.1095/biolreprod53.1.166)

Diotel N, Vaillant C, Gabbero C, Mironov S, Fostier A, Gueguen MM, Anglade I, Kah O \& Pellegrini E 2013 Effects of estradiol in adult neurogenesis and brain repair in zebrafish. Hormones and Behavior 63 193-207. (https://doi.org/10.1016/j.yhbeh.2012.04.003)

Egami N 1975 Secondary sexual characters. In Medaka (Killifish): Biology and Strains, pp 109-125. Ed T Yamamoto. Tokyo: Keigaku Publishing Company.

Fauquier DA, Mazet JAK, Gulland FMD, Spraker TR \& Christopher MM $2008 a$ Distribution of tissue enzymes in three species of pinnipeds. Journal of Zoo and Wildlife Medicine 39 1-5. (https://doi. org/10.1638/2006-0012.1)

Fauquier T, Rizzoti K, Dattani M, Lovell-Badge R \& Robinson ICAF $2008 b$ SOX2-expressing progenitor cells generate all of the major cell types in the adult mouse pituitary gland. PNAS 105 2907-2912. (https:// doi.org/10.1073/pnas.0707886105)

Fontaine R, Affaticati P, Yamamoto K, Jolly C, Bureau C, Baloche S, Gonnet F, Vernier P, Dufour S \& Pasqualini C 2013 Dopamine inhibits reproduction in female zebrafish (Danio rerio) via three pituitary D2 receptor subtypes. Endocrinology 154 807-818. (https://doi. org/10.1210/en.2012-1759)

Germana A, Montalbano G, Guerrera MC, Amato V, Laura R, Magnoli D, Campo S, Suarez-Fernandez E, Ciriaco E \& Vega JA 2011 Developmental changes in the expression of Sox 2 in the zebrafish brain. Microscopy Research and Technique 74 347-354. (https://doi. org/10.1002/jemt.20915)

Golan M, Biran J \& Levavi-Sivan B 2014 A novel model for development, organization, and function of gonadotropes in fish pituitary. Frontiers in Endocrinology 5 182. (https://doi.org/10.3389/fendo.2014.00182)
(C) 2019 Society for Endocrinology Published by Bioscientifica Ltd. Printed in Great Britain 
Hahn AT, Jones JT \& Meyer T 2009 Quantitative analysis of cell cycle phase durations and PC12 differentiation using fluorescent biosensors. Cell Cycle 8 1044-1052. (https://doi.org/10.4161/ cc.8.7.8042)

Hansen KD, Irizarry RA \& Wu Z 2012 Removing technical variability in RNA-seq data using conditional quantile normalization. Biostatistics 13 204-216. (https://doi.org/10.1093/biostatistics/kxr054)

Henseler J, Ringle C \& Sinkovics R 2009 The use of partial least squares path modeling in international marketing. In New Challenges to International Marketing, pp 277-319. Ed PNG Rudolf R. Sinkovics: Emerald Group Publishing Limited.

Hildahl J, Sandvik GK, Lifjeld R, Hodne K, Nagahama Y, Haug TM, Okubo K \& Weltzien FA 2012 Developmental tracing of luteinizing hormone beta-subunit gene expression using green fluorescent protein transgenic medaka (Oryzias latipes) reveals a putative novel developmental function. Developmental Dynamics 241 1665-1677. (https://doi.org/10.1002/dvdy.23860)

Huysentruyt F, Moerkerke B, Devaere S \& Adriaens D 2009 Early development and allometric growth in the armoured catfish Corydoras aeneus (Gill, 1858). Hydrobiologia 627 45-54. (https://doi. org/10.1007/s10750-009-9714-z)

Kah O, Pellegrini E, Mouriec K, Diotel N, Anglade I, Vaillant C, Thieulant ML, Tong SK, Brion F, Chung BC, et al. 2009 Oestrogens and neurogenesis: new functions for an old hormone. Lessons from the zebrafish. Journal de la Société de Biologie 203 29-38. (https://doi org/10.1051/jbio:2009007)

Kanda S, Okubo K \& Oka Y 2011 Differential regulation of the luteinizing hormone genes in teleosts and tetrapods due to their distinct genomic environments - insights into gonadotropin beta subunit evolution. General and Comparative Endocrinology 173 253-258. (https://doi. org/10.1016/j.ygcen.2011.05.015)

Karigo T, Kanda S, Takahashi A, Abe H, Okubo K \& Oka Y 2012 Timeof-day-dependent changes in GnRH1 neuronal activities and gonadotropin mRNA expression in a daily spawning fish, medaka. Endocrinology 153 3394-3404. (https://doi.org/10.1210/en.2011-2022)

Kelberman D, Rizzoti K, Lovell-Badge R, Robinson ICAF \& Dattani MT 2009 Genetic regulation of pituitary gland development in human and mouse. Endocrine Reviews 30 790-829. (https://doi.org/10.1210/ er.2009-0008)

Kim M, Gee M, Loh A \& Rachatasumrit N 2010 Ref-finder: a refactoring reconstruction tool based on logic query templates. In Proceedings of the Eighteenth ACM SIGSOFT International Symposium on Foundations of Software Engineering, SER. FSE '10, pp 371-372. Ed A Press. New York.

Lam CS, Marz M \& Strahle U 2009 Gfap and nestin reporter lines reveal characteristics of neural progenitors in the adult zebrafish brain. Developmental Dynamics 238 475-486. (https://doi.org/10.1002/ dvdy.21853)

Li G, Tang H, Chen Y, Yin Y, Ogawa S, Liu M, Guo Y, Qi X, Liu Y, Parhar IS, et al. 2018 Estrogen directly stimulates LHb expression at the pituitary level during puberty in female zebrafish. Molecular and Cellular Endocrinology 461 1-11. (https://doi.org/10.1016/j. mce.2017.08.003)

Lindsey BW \& Tropepe V 2006 A comparative framework for understanding the biological principles of adult neurogenesis. Progress in Neurobiology 80 281-307. (https://doi.org/10.1016/j. pneurobio.2006.11.007)

Lindzey J, Jayes FL, Yates MM, Couse JF \& Korach KS 2006 The bi-modal effects of estradiol on gonadotropin synthesis and secretion in female mice are dependent on estrogen receptor-alpha. Journal of Endocrinology 191 309-317. (https://doi.org/10.1677/joe.1.06965)

Liu TC \& Jackson GL 1977 Effect of in vivo treatment with estrogen on luteinizing hormone synthesis and release by rat pituitaries in vitro. Endocrinology 100 1294-1302. (https://doi.org/10.1210/endo-100-51294)
Lust K \& Wittbrodt J 2018 Activating the regenerative potential of Muller glia cells in a regeneration-deficient retina. ELife 7 e32319. (https:// doi.org/10.7554/eLife.32319)

Martinez-Cerdeno V, Noctor SC \& Kriegstein AR 2006 Estradiol stimulates progenitor cell division in the ventricular and subventricular zones of the embryonic neocortex. European Journal of Neuroscience 24 3475-3488. (https://doi.org/10.1111/j.14609568.2006.05239.x)

Marz M, Chapouton P, Diotel N, Vaillant C, Hesl B, Takamiya M, Lam CS, Kah O, Bally-Cuif L \& Strahle U 2010 Heterogeneity in progenitor cell subtypes in the ventricular zone of the zebrafish adult telencephalon. Glia 58 NA-NA. (https://doi.org/10.1002/glia.20971)

Matsuda M, Nagahama Y, Shinomiya A, Sato T, Matsuda C, Kobayashi T, Morrey CE, Shibata N, Asakawa S, Shimizu N, et al. 2002 DMY is a $\mathrm{Y}$-specific DM-domain gene required for male development in the medaka fish. Nature $\mathbf{4 1 7}$ 559-563. (https://doi.org/10.1038/nature751)

Matsuda M, Shinomiya A, Kinoshita M, Suzuki A, Kobayashi T, PaulPrasanth B, Lau E-l, Hamaguchi S, Sakaizumi M \& Nagahama Y 2007 DMY gene induces male development in genetically female (XX) Medaka fish. PNAS 104 3865-3870. (https://doi.org/10.1073/ pnas.0611707104)

Mollard P, Hodson DJ, Lafont C, Rizzoti K \& Drouin J 2012 A tridimensional view of pituitary development and function. Trends in Endocrinology and Metabolism 23 261-269. (https://doi.org/10.1016/j. tem.2012.02.004)

Mouriec K, Pellegrini E, Anglade I, Menuet A, Adrio F, Thieulant ML, Pakdel F \& Kah O 2008 Synthesis of estrogens in progenitor cells of adult fish brain: evolutive novelty or exaggeration of a more general mechanism implicating estrogens in neurogenesis? Brain Research Bulletin 75 274-280. (https://doi.org/10.1016/j. brainresbull.2007.10.030)

Nanda I, Kondo M, Hornung U, Asakawa S, Winkler C, Shimizu A, Shan Z, Haaf T, Shimizu N, Shima A, et al. 2002 A duplicated copy of DMRT1 in the sex-determining region of the Y chromosome of the medaka, Oryzias latipes. PNAS 99 11778-11783. (https://doi. org/10.1073/pnas.182314699)

Noctor SC, Flint AC, Weissman TA, Dammerman RS \& Kriegstein AR 2001 Neurons derived from radial glial cells establish radial units in neocortex. Nature 409 714-720. (https://doi.org/10.1038/35055553)

Nozaki M, Naito N, Swanson P, Dickhoff WW, Nakai Y, Suzuki K \& Kawauchi H 1990 Salmonid pituitary gonadotrophs. II. Ontogeny of GTH I and GTH II cells in the rainbow trout (Salmo gairdneri irideus). General and Comparative Endocrinology 77 358-367. (https://doi. org/10.1016/0016-6480(90)90225-B)

Okubo K, Takeuchi A, Chaube R, Paul-Prasanth B, Kanda S, Oka Y \& Nagahama Y 2011 Sex differences in aromatase gene expression in the medaka brain. Journal of Neuroendocrinology 23 412-423. (https://doi. org/10.1111/j.1365-2826.2011.02120.x)

Osse JWM \& Boogaart JGMvd 1995 Fish larvae, development, allometric growth and the aquatic environment. ICES Marine Science Symposia $20121-34$

Parsons GG \& Spencer CA 1997 Mitotic repression of RNA polymerase II transcription is accompanied by release of transcription elongation complexes. Molecular and Cellular Biology 17 5791-5802. (https://doi. org/10.1128/МСВ.17.10.5791)

Pellegrini E, Mouriec K, Anglade I, Menuet A, Le Page Y, Gueguen MM, Marmignon MH, Brion F, Pakdel F \& Kah O 2007 Identification of aromatase-positive radial glial cells as progenitor cells in the ventricular layer of the forebrain in zebrafish. Journal of Comparative Neurology 501 150-167. (https://doi.org/10.1002/cne.21222)

Pogoda HM \& Hammerschmidt M 2009 How to make a teleost adenohypophysis: molecular pathways of pituitary development in zebrafish. Molecular and Cellular Endocrinology 312 2-13. (https://doi. org/10.1016/j.mce.2009.03.012) 
Pope C, McNeilly JR, Coutts S, Millar M, Anderson RA \& McNeilly AS 2006 Gonadotrope and thyrotrope development in the human and mouse anterior pituitary gland. Developmental Biology 297 172-181. (https://doi.org/10.1016/j.ydbio.2006.05.005)

Porter TE, Wiles CD \& Frawley LS 1991 Evidence for bidirectional interconversion of mammotropes and somatotropes: rapid reversion of acidophilic cell types to pregestational proportions after weaning. Endocrinology 129 1215-1220. (https://doi.org/10.1210/endo-129-31215)

Prescott DM \& Bender MA 1962 Synthesis of RNA and protein during mitosis in mammalian tissue culture cells. Experimental Cell Research 26 260-268. (https://doi.org/10.1016/0014-4827(62)90176-3)

Rothenaigner I, Krecsmarik M, Hayes JA, Bahn B, Lepier A, Fortin G, Gotz M, Jagasia R \& Bally-Cuif L 2011 Clonal analysis by distinct viral vectors identifies bona fide neural stem cells in the adult zebrafish telencephalon and characterizes their division properties and fate. Development 138 1459-1469. (https://doi.org/10.1242/ dev.058156)

Sakuma S, Shirasawa N \& Yoshimura F 1984 A histometrical study of immunohistochemically identified mitotic adenohypophysial cells in immature and mature castrated rats. Journal of Endocrinology $\mathbf{1 0 0}$ 323-328. (https://doi.org/10.1677/joe.0.1000323)

Schindelin J, Arganda-Carreras I, Frise E, Kaynig V, Longair M, Pietzsch T, Preibisch S, Rueden C, Saalfeld S, Schmid B, et al. 2012 Fiji: an open-source platform for biological-image analysis. Nature Methods 9 676-682. (https://doi.org/10.1038/nmeth.2019)

Schmid B, Schindelin J, Cardona A, Longair M \& Heisenberg M 2010 A high-level 3D visualization API for Java and ImageJ. BMC Bioinformatics 11 274. (https://doi.org/10.1186/1471-2105-11-274)

Schmitz M, Aroua S, Vidal B, Le Belle N, Elie P \& Dufour S 2005 Differential regulation of luteinizing hormone and follicle-stimulating hormone expression during ovarian development and under sexual steroid feedback in the European eel. Neuroendocrinology 81 107-119. (https://doi.org/10.1159/000086404)

Shima A \& Mitani H 2004 Medaka as a research organism: past, present and future. Mechanisms of Development 121 599-604. (https://doi. org/10.1016/j.mod.2004.03.011)

Simpson ER \& Davis SR 2001 Minireview: aromatase and the regulation of estrogen biosynthesis - some new perspectives. Endocrinology 142 4589-4594. (https://doi.org/10.1210/endo.142.11.8547)

Smith PF \& Keefer DA 1982 Immunocytochemical and ultrastructural identification of mitotic cells in the pituitary gland of ovariectomized rats. Reproduction 66 383-388. (https://doi. org/10.1530/jrf.0.0660383)

So WK, Kwok HF \& Ge W 2005 Zebrafish gonadotropins and their receptors: II. Cloning and characterization of zebrafish folliclestimulating hormone and luteinizing hormone subunits - their spatial-temporal expression patterns and receptor specificity. Biology of Reproduction 72 1382-1396. (https://doi.org/10.1095/ biolreprod.104.038216)

Takahashi S 1995 Development and heterogeneity of prolactin cells. International Review of Cytology 157 33-98.
Taniguchi Y, Yasutaka S, Kominami R \& Shinohara H 2002 Proliferation and differentiation of rat anterior pituitary cells. Anatomy and Embryology 206 1-11. (https://doi.org/10.1007/s00429-002-0271-8)

Taylor JH 1960 Nucleic acid synthesis in relation to the cell division cycle. Annals of the New York Academy of Sciences 90 409-421. (https:// doi.org/10.1111/j.1749-6632.1960.tb23259.x)

Turrero Garcia M, Chang Y, Arai Y \& Huttner WB 2016 S-phase duration is the main target of cell cycle regulation in neural progenitors of developing ferret neocortex. Journal of Comparative Neurology $\mathbf{5 2 4}$ 456-470. (https://doi.org/10.1002/cne.23801)

Untergasser A, Nijveen H, Rao X, Bisseling T, Geurts R \& Leunissen JAM 2007 Primer3Plus, an enhanced web interface to Primer3. Nucleic Acids Research 35 W71-W74. (https://doi.org/10.1093/nar/gkm306)

Van Snik GMJ, van den Boogaart JGM \& Osse JWM 1997 Larval growth patterns in Cyprinus carpio and Clarias gariepinus with attention to the finfold. Journal of Fish Biology 50 1339-1352. (https://doi. org/10.1111/j.1095-8649.1997.tb01657.x)

Von Krogh K, Bjorndal GT, Nourizadeh-Lillabadi R, Hodne K, Ropstad E, Haug TM \& Weltzien FA 2017 Sex steroids differentially regulate fshb, lhb and gnrhr expression in Atlantic cod (Gadus morhua). Reproduction 154 581-594. (https://doi.org/10.1530/REP17-0208)

Weltzien FA, Pasqualini C, Vernier P \& Dufour S 2005 A quantitative realtime RT-PCR assay for European eel tyrosine hydroxylase. General and Comparative Endocrinology 142 134-142. (https://doi.org/10.1016/j. ygcen.2004.12.019)

Weltzien FA, Hildahl J, Hodne K, Okubo K \& Haug TM 2014 Embryonic development of gonadotrope cells and gonadotropic hormones lessons from model fish. Molecular and Cellular Endocrinology 385 18-27. (https://doi.org/10.1016/j.mce.2013.10.016)

Wittbrodt J, Shima A \& Schartl M 2002 Medaka - a model organism from the far East. Nature Reviews Genetics 3 53-64. (https://doi.org/10.1038/ nrg704)

Yaron Z, Gur G, Melamed P, Rosenfeld H, Elizur A \& Levavi-Sivan B 2003 Regulation of fish gonadotropins. International Review of Cytology 225 131-185.

Zempo B, Kanda S, Okubo K, Akazome Y \& Oka Y 2013 Anatomical distribution of sex steroid hormone receptors in the brain of female medaka. Journal of Comparative Neurology 521 1760-1780. (https://doi. org/10.1002/cne.23255)

Zhang X, Hecker M, Park JW, Tompsett AR, Newsted J, Nakayama K, Jones PD, Au D, Kong R, Wu RSS, et al. 2008 Real-time PCR array to study effects of chemicals on the hypothalamic-pituitary-gonadal axis of the Japanese medaka. Aquatic Toxicology 88 173-182. (https:// doi.org/10.1016/j.aquatox.2008.04.009)

Zohar Y 1988 Gonadotropin Releasing Hormone in Spawning Induction in Teleosts: Basic and Applied Considerations. Eilat (Israel): Israel Oceanographic and Limnological Research, National Center for Mariculture.

Zohar Y, Munoz-Cueto JA, Elizur A \& Kah O 2010 Neuroendocrinology of reproduction in teleost fish. General and Comparative Endocrinology 165 438-455. (https://doi.org/10.1016/j.ygcen.2009.04.017)

Received in final form 18 October 2018

Accepted 30 November 2018

Accepted Preprint published online 3 December 2018 https://joe.bioscientifica.com https://doi.org/10.1530/JOE-18-0412
(C) 2019 Society for Endocrinology Published by Bioscientifica Ltd. 